\title{
Targeting mutant p53 for cancer therapy: direct and indirect strategies
}

\author{
Jiahao $\mathrm{Hu}^{1,2+}$, Jiasheng Cao ${ }^{1,2+}$, Win Topatana ${ }^{1,2+}$, Sarun Juengpanich², Shijie Li ${ }^{2}$, Bin Zhang ${ }^{2}$, Jiliang Shen ${ }^{1}$, \\ Liuxin Cai ${ }^{1}$, Xiujun Cai ${ }^{1,2,3,4^{*}}$ and Mingyu Chen ${ }^{1,2,3^{*}}$ (D)
}

\begin{abstract}
TP53 is a critical tumor-suppressor gene that is mutated in more than half of all human cancers. Mutations in TP53 not only impair its antitumor activity, but also confer mutant p53 protein oncogenic properties. The p53-targeted therapy approach began with the identification of compounds capable of restoring/reactivating wild-type p53 functions or eliminating mutant p53. Treatments that directly target mutant p53 are extremely structure and drug-speciesdependent. Due to the mutation of wild-type $\mathrm{p} 53$, multiple survival pathways that are normally maintained by wild-type p53 are disrupted, necessitating the activation of compensatory genes or pathways to promote cancer cell survival. Additionally, because the oncogenic functions of mutant p53 contribute to cancer proliferation and metastasis, targeting the signaling pathways altered by p53 mutation appears to be an attractive strategy. Synthetic lethality implies that while disruption of either gene alone is permissible among two genes with synthetic lethal interactions, complete disruption of both genes results in cell death. Thus, rather than directly targeting p53, exploiting mutant p53 synthetic lethal genes may provide additional therapeutic benefits. Additionally, research progress on the functions of noncoding RNAs has made it clear that disrupting noncoding RNA networks has a favorable antitumor effect, supporting the hypothesis that targeting noncoding RNAs may have potential synthetic lethal effects in cancers with p53 mutations. The purpose of this review is to discuss treatments for cancers with mutant p53 that focus on directly targeting mutant p53, restoring wild-type functions, and exploiting synthetic lethal interactions with mutant p53. Additionally, the possibility of noncoding RNAs acting as synthetic lethal targets for mutant p53 will be discussed.
\end{abstract}

Keywords: p53, Cancer therapy, MDM2 inhibitor, p53 restoration, Synthetic lethality, Noncoding RNA

\section{Introduction}

The tumor-suppressor p53, encoded by the TP53 gene (or Trp53 in mice), is critical for normal cell growth and tumor prevention $[1,2]$. Generally, the p53 protein is kept at a low level in normal tissue by its negative regulator, mouse double minute 2/X (MDM2/X) [3]. Numerous endogenous and exogenous stressors can activate $\mathrm{p} 53$, triggering it to further regulate a series of cellular

\footnotetext{
*Correspondence: srrsh_cxj@zju.edu.cn; mychen@zju.edu.cn

${ }^{\dagger} J$ iahao Hu, Jiasheng Cao and Win Topatana have contributed equally to this work

${ }^{1}$ Department of General Surgery, Sir Run-Run Shaw Hospital, Zhejiang University, No. 3 East Qingchun Road, Hangzhou 310016, China

Full list of author information is available at the end of the article
}

responses necessary for homeostasis maintenance (Fig. 1) [4]. The activation of p53 in response to multiple stresses is critical for normal cells to survive and protect themselves from tumorigenesis. However, TP53 is frequently mutated in most human cancers, resulting in the loss of functions (LOFs) necessary for tumor suppression and even the gain of functions (GOFs) necessary for tumor growth $[5,6]$. The most common p53 mutation is the missense mutation in the DNA-binding domain (DBD), which affects only one amino acid in the p53 protein but has a significant effect on the protein's function [7]. Tumors harbor p53 mutations frequently progress more rapidly, have a poor response to anticancer therapy, and original author(s) and the source, provide a link to the Creative Commons licence, and indicate if changes were made. The images or other third party material in this article are included in the article's Creative Commons licence, unless indicated otherwise in a credit line to the material. If material is not included in the article's Creative Commons licence and your intended use is not permitted by statutory regulation or exceeds the permitted use, you will need to obtain permission directly from the copyright holder. To view a copy of this licence, visit http://creativecommons.org/licenses/by/4.0/. The Creative Commons Public Domain Dedication waiver (http://creativeco mmons.org/publicdomain/zero/1.0/) applies to the data made available in this article, unless otherwise stated in a credit line to the data. 


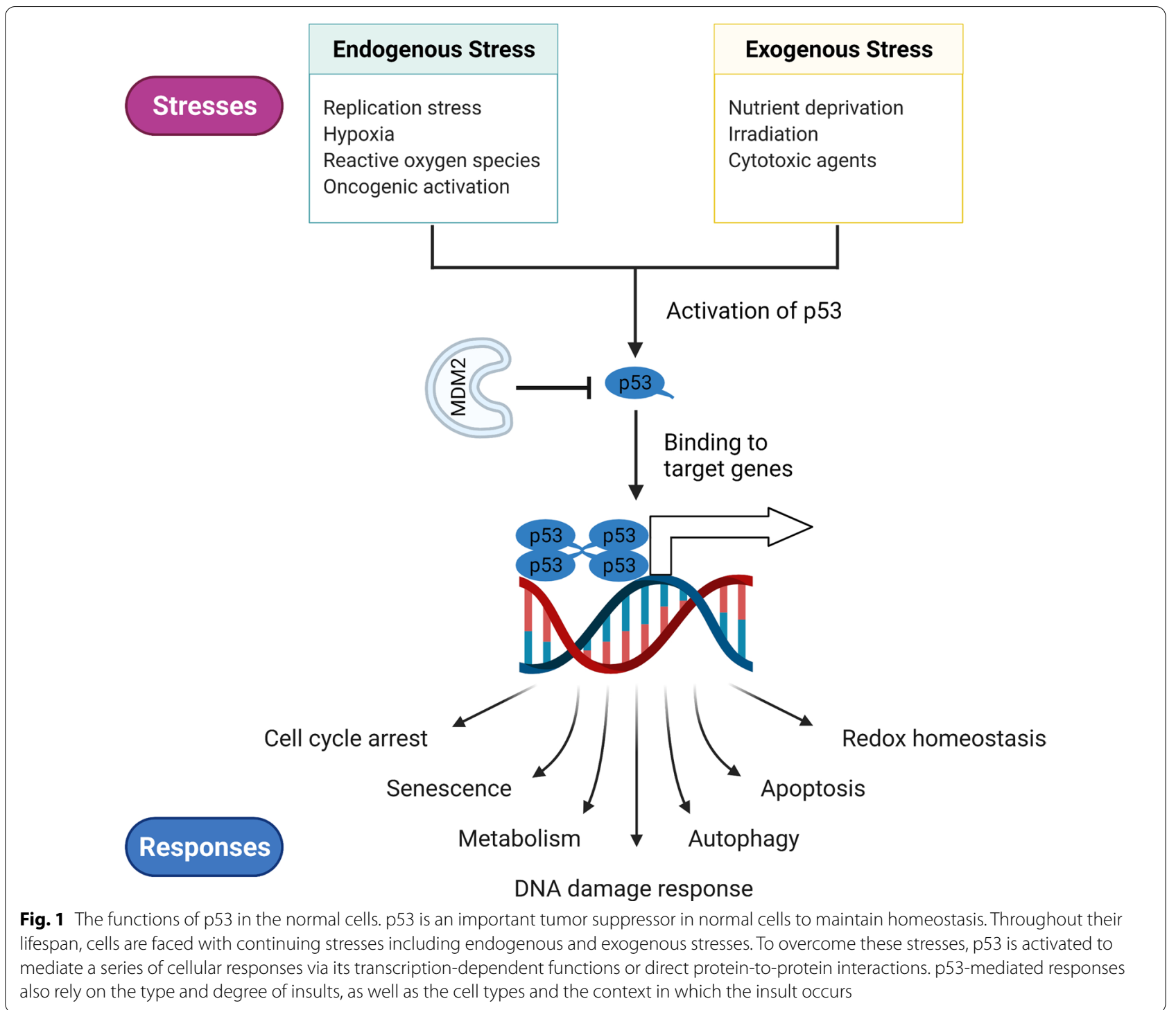

have a poor prognosis $[6,8,9]$. Therefore, targeting p53 for cancer therapy is an attractive strategy.

Depending on the p53 status, p53 treatments may include preventing the degradation of wild-type p53 (wtp53), suppressing mutant p53 (mutp53), or restoring the wild-type functions of mutp53 [10,11]. Agents that protect wtp53 primarily act by interfering with the interactions of p53 and its negative regulators, most notably MDM2, to prevent subsequent ubiquitination [12]. Increased wtp53 levels are sufficient to induce tumorsuppressive responses [13]. Different strategies for restoring p53 functions have been developed based on the variety of mutp53 protein structures as well as their specific functional deficiencies [14]. Additionally, p53 GOF mutations confer oncogenic properties on cancer cells, and thus, targeting these specific mutations may inhibit cancer cell proliferation [15]. Despite their relative advantages, these treatments have a very limited effect due to the prevalence of mutp53 variants. Thus, a superior strategy that specifically targets the majority of mutant p53 can result in greater therapeutic benefit for patients.

Since the successful use of the PARP1 inhibitor olaparib in the treatment of cancers caused by $B R C A 1$ and $B R C A 2$ mutations, such as breast, ovarian, pancreatic, and prostate cancers, synthetic lethality-based anticancer therapy has garnered enormous attention [16]. The term "synthetic lethality" was originated in Drosophila research and refers to the fact that disrupting partial genes via synthetic lethal interactions is feasible but lethal $[17,18]$. As a result, exploiting and targeting 
synthetic lethal partners may become an attractive therapeutic strategy for unmodifiable genes. TP53 is an example of an "undruggable" gene that frequently loses its normal functions and activates a cascade of signaling pathways to promote tumor progression and compensate for the loss of functions. Numerous synthetic lethality partners may be concealed within these altered pathways. As one of the most prominent functions of $\mathrm{p} 53$, it is not surprising that researchers screen for $\mathrm{p} 53$ synthetic lethal partners associated with the cell cycle. Mutp53-positive cancers lose their capacity to induce G1 arrest, which is maintained by wtp53 and its transcriptionally activated p21 [19]. Following DNA damage, cancer cells harboring mutp53 are protected from accumulated replication stress (RS) and mitotic catastrophe by intra-S and G2 arrest, which are regulated by multiple factors [20, 21]. The G2 checkpoint contains the first identified synthetic lethal interaction with p53-deficient cancer cells [22]. Tumors lacking p53 are particularly susceptible to G2 checkpoint abrogation when exposed to DNA damage. Certain regulators of the S and G2 arrest have been shown to be synthetic lethal to p53. However, researchers are intrigued by alternative p53-mediated pathways that have a synthetic lethal effect when combined with mutp53. Additionally, synthetic lethality is a genetic concept, and its realization ultimately requires the disruption of protein functions. With the growing body of knowledge about the functions of noncoding RNAs (ncRNAs), we can assume that a synthetic lethal interaction occurs when the synthetic lethal partner is disrupted in the field of ncRNAs. ncRNAs are RNAs that do not encode proteins but have roles in a variety of processes such as modulating DNA transcription, regulating mRNA degradation, and they act as miRNA sponges and interact with DNA, RNA, or proteins [23]. Modulating ncRNAs can further affect their regulation of cellular responses and signaling pathways, which makes them potential targets for drug development.

In this study, we discussed therapeutic strategies targeting p53, ranging from direct targeting to synthetic lethal interactions with mutant p53. Additionally, as research into the functions of ncRNAs continues to progress, we addressed the synthetic lethal targets of mutp53 in the field of ncRNAs.

\section{Targeting p53 for cancer therapy}

Numerous studies elucidated the roles of p53 in tumor progression since its discovery forty years ago. However, mutant forms of the tumor-suppressor p53 not only lose their tumor-suppressive properties but also frequently acquire tumor-promoting properties [2]. The development of p53-targeted drugs is particularly difficult because the agent must specifically target mutp53 in cancer cells while having no effect on normal cells harboring wtp53 [24]. Additionally, multiple p53 mutations result in various mutp53 protein structures that are difficult to target [25]. Major therapeutic strategies targeting p53 can be classified into two categories based on their p53 status: restoring wtp53 functions and eradicating mutp53 [8, 26-28].

\section{Reactivating suppressed $\mathrm{p} 53$ functions}

While intact TP53 is present in some cancers, the tumor suppressor is always inhibited via a variety of mechanisms. MDM2 is the major negative regulator of p53, which prevents 553 from entering the nucleus, inhibits its DNA binding, and promotes p53 proteasomal degradation $[29,30]$. Genetic amplification is the most frequent genomic alteration of MDM2, which was first found in soft-tissue sarcoma [31]. It was discovered that amplification and overexpression of MDM2 were mutually exclusive with p53 mutation [32]. Oliner et al. discovered that MDM2 overexpression involved intact p53 across cancer types in a study using The Cancer Genome Atlas (TCGA) database [33]. Thus, inhibiting MDMs in cancers with wtp53 is an intriguing therapeutic strategy that has been successfully applied in clinical settings (Table 1). Since the discovery of a class of cis-imidazoline analogues known as nutlins that inhibit p53-MDM2 binding, MDM2 inhibitors have been extensively studied as a targeted treatment for patients with wtp53 [12, 34]. Nutlin-3a, a preclinical drug, inhibits tumor growth by reactivating wild-type $\mathrm{p} 53$, whether used alone or in combination with other therapies [35-37]. Due to the promising results of in vitro studies, clinical trials were conducted to assess the efficacy and safety of the derivative of nutlins, RG7112 (RO5045337) [38]. The majority of patients who accepted treatment with RG7112 had a stable disease. While nutlins can strongly activate wtp53 in tumors overexpressing MDM2, they are unable to activate the p53 pathway in cancers overexpressing MDMX due to subtle differences in the $\mathrm{N}$-terminal p53-binding pocket of MDMX [39]. ALRN-6924 was the only dual MDM2 and MDMX inhibitor to reach clinical trials after preclinical investigations revealed a considerable antitumor effect $[40,41]$. Since MDM2 and MDMX have distinct anti-p53 activities, dual antagonists targeting both p53-MDM2 and p53-MDMX may have a greater effect than inhibiting either pathway alone.

While MDM2 inhibitors demonstrate a modest clinical response, the adverse events associated with their ontarget effects should be considered [42]. Thus, combining MDM2 inhibitors with therapies such as chemotherapy, BCL2 inhibitors, CDK inhibitors, immunotherapy, or PI3K, MEK, and FLT3-ITD pathway inhibition is a better approach to reduce adverse events and improve 
Table 1 Clinical trial agents targeting p53 negative regulators

\begin{tabular}{|c|c|c|c|c|c|}
\hline $\begin{array}{l}\text { ClinicalTrial.gov } \\
\text { identifier and } \\
\text { reference }\end{array}$ & Study design & $\begin{array}{l}\text { Intervention and } \\
\text { sample size }(n)\end{array}$ & Outcomes (n) & Toxicities $(n)$ & Conclusions \\
\hline $\begin{array}{l}\text { NCT02016729; Erba } \\
\text { et al. [146] }\end{array}$ & $\begin{array}{l}\text { Non-randomized } \\
\text { phase 1, open label }\end{array}$ & $\begin{array}{l}\text { AMG232 (26) } \\
\text { AMG232 + trametinib } \\
\text { (10) }\end{array}$ & $\begin{array}{l}\text { MLFS (4) } \\
\text { CR (1), PR (1) }\end{array}$ & $\begin{array}{l}\text { AEs (25) } \\
\operatorname{AEs}(10)\end{array}$ & $\begin{array}{l}\text { AMG232 is activate and } \\
\text { tolerable }\end{array}$ \\
\hline $\begin{array}{l}\text { NCT01164033, Patnaik } \\
\text { et al. [147] }\end{array}$ & $\begin{array}{l}\text { Randomized phase 1, } \\
\text { open label }\end{array}$ & $\begin{array}{l}\text { RG7112 single dose } \\
\text { (23) } \\
\text { RG7112 multiple dose } \\
(53)\end{array}$ & $\begin{array}{l}\mathrm{N} / \mathrm{A} \\
\mathrm{SD}(6)\end{array}$ & $\begin{array}{l}\text { AEs (16), SAEs (2) } \\
\text { AEs (52), SAEs (13) }\end{array}$ & $\begin{array}{l}\text { High-dose consecutive is } \\
\text { superior }\end{array}$ \\
\hline $\begin{array}{l}\text { NCT00623870; } \\
\text { Andreeff et al. [61] }\end{array}$ & Phase 1, open label & $\begin{array}{l}\text { RG7112 for AML (96) } \\
\text { RG7112 for CML (20) }\end{array}$ & $\begin{array}{l}C R(2), C R_{p}(1), P R \\
(1), M L F S(1), M T D \\
(1500 \mathrm{mg} \text { BID), DLTs (3) } \\
\text { PR (1), SD (15), MTD } \\
\text { (N/A), DLTs (N/A) }\end{array}$ & $\begin{array}{l}A E \text { grade } \geq 3(86), A E \\
\text { grade } \geq 4(34)\end{array}$ & $\begin{array}{l}\text { RG7112 is activated } \\
\text { but need combination } \\
\text { therapy }\end{array}$ \\
\hline $\begin{array}{l}\text { NCT02098967; Uy and } \\
\text { Razak et al. }[148,149]\end{array}$ & $\begin{array}{l}\text { Non-randomized } \\
\text { phase 1, open label }\end{array}$ & $\begin{array}{l}\text { RG7775 for AML (26) } \\
\text { RG775 for solid tumor } \\
\text { (41) }\end{array}$ & $\begin{array}{l}\text { CR (2), PR (2), HI/SD (7), } \\
\text { MTD ( } 200 \mathrm{mg}), \text { DLTs (4) } \\
\text { SD (17), MTD (110 mg), } \\
\text { DLTs (5) }\end{array}$ & $\begin{array}{l}\text { AEs (25), SAEs (22) } \\
\text { AEs (40), SAEs (6), } \\
\text { death (2) }\end{array}$ & $\begin{array}{l}\text { No improvement of } \\
\text { safety }\end{array}$ \\
\hline $\begin{array}{l}\text { NCT02264613; Saleh } \\
\text { et al. [150] }\end{array}$ & $\begin{array}{l}\text { Non-randomized } \\
\text { phase } 1 / 2 \text {, open label }\end{array}$ & $\begin{array}{l}\text { ALRN-6924: 0.16- } \\
4.4 \text { mg/kg (41) } \\
\text { ALRN-6924: 0.32- } \\
2.7 \text { mg/kg (41) }\end{array}$ & $\begin{array}{l}\text { CR (1), PR (1), SD (12), } \\
\operatorname{DLTs}(5) \\
\text { CR (1), PR (8), SD (8), } \\
\text { DLTs (0) }\end{array}$ & $\begin{array}{l}\text { SAES (7) } \\
\text { SAES (1) }\end{array}$ & $\begin{array}{l}\text { ALRN-6924 is activated } \\
\text { and tolerable }\end{array}$ \\
\hline $\begin{array}{l}\text { NCT01462175; Italiano } \\
\text { et al. [151] }\end{array}$ & $\begin{array}{l}\text { Non-randomized } \\
\text { phase 1, open label }\end{array}$ & $\begin{array}{l}\text { RG7388 QW*3 (36) } \\
\text { RG7388 QD*3 (15) } \\
\text { RG7388 QD*5 (34) }\end{array}$ & $\begin{array}{l}\text { SD (10), MTD (1600 mg } \\
\text { BID) } \\
\text { SD (5), MTD (500 mg } \\
\text { BID) } \\
\text { SD (8), MTD (500 mg } \\
\text { QD) }\end{array}$ & $\begin{array}{l}\text { AEs (10), death (2) } \\
\text { AEs (12) } \\
\text { AEs (27), death (4) }\end{array}$ & $\begin{array}{l}\text { RG7388 induces durable } \\
\text { SD }\end{array}$ \\
\hline $\begin{array}{l}\text { NCT01773408; Yee } \\
\text { et al. [44] }\end{array}$ & $\begin{array}{l}\text { Non-randomized } \\
\text { phase 1, open label }\end{array}$ & $\begin{array}{l}\text { Idasanutlin (46) } \\
\text { Idasanutlin-C (76) }\end{array}$ & $\begin{array}{l}\mathrm{CR}_{c}(7) \\
\mathrm{CR}_{c}(21)\end{array}$ & $\begin{array}{l}\text { AE grade } \geq 3 \text { (31), SAEs } \\
\text { (24), death (11) } \\
\text { AE grade } \geq 3(69) \text {, SAEs } \\
\text { (48), death (16) }\end{array}$ & $\begin{array}{l}\text { Idasanutlin is activated } \\
\text { and safety }\end{array}$ \\
\hline $\begin{array}{l}\text { NCT02545283; Papai } \\
\text { et al. [152] }\end{array}$ & $\begin{array}{l}\text { Non-randomized } \\
\text { phase 1, open label }\end{array}$ & $\begin{array}{l}{\left[{ }^{13 / 14} \mathrm{C}\right] \text {-label idasanut- }} \\
\operatorname{lin}(8)\end{array}$ & $\mathrm{SD}(1)$ & $\mathrm{N} / \mathrm{A}$ & $\begin{array}{l}\text { Hepatic impair alters } \\
\text { idasanutlin exposure }\end{array}$ \\
\hline $\begin{array}{l}\text { NCT01760525; Bauer } \\
\text { et al. [153] }\end{array}$ & $\begin{array}{l}\text { Non-randomized } \\
\text { phase 1, openlabel }\end{array}$ & $\begin{array}{l}\text { CGM097 } 400 \text { mg } \\
\text { QW*3 (31) } \\
\text { CMG097 300-700 mg } \\
\text { QW*3 (20) }\end{array}$ & $\begin{array}{l}\operatorname{PR}(1), S D(10) \\
\text { SD (9) }\end{array}$ & $\begin{array}{l}A E \text { grade } \geq 3(25), A E \\
\text { grade } \geq 4(12)\end{array}$ & $\begin{array}{l}\text { CMG097 is tolerable with } \\
\text { partial efficacy }\end{array}$ \\
\hline $\begin{array}{l}\text { NCT02143635; Jeay } \\
\text { et al. [154] }\end{array}$ & $\begin{array}{l}\text { Non-randomized } \\
\text { phase 1, open label }\end{array}$ & $\begin{array}{l}\text { HDM201 daily (20) } \\
\text { HDM201 QW*3 (24) }\end{array}$ & $\mathrm{N} / \mathrm{A}$ & N/A & $\begin{array}{l}\text { Intermittent regimen is } \\
\text { better }\end{array}$ \\
\hline
\end{tabular}

MLFS: morphologic leukemia-free state; CR: complete response; PR: partial response; AEs: adverse events; SD: stable disease; $C R_{\mathrm{p}}$ : complete remission without platelet recovery; MTD: maximum tolerated dose; BID: twice daily; DLTs: dose-limiting toxicities; HI: hematologic improvement; SAEs: serious adverse events; QW: once weekly; $\mathrm{QD}$ : once daily; $\mathrm{CR}_{\mathrm{c}}$ : composite complete remission

therapeutic efficacy [43]. A majority of studies were conducted to determine the safety, pharmacokinetics, pharmacodynamics, and antitumor efficacy of these drugs. According to the results of a phase I study, when RG7388 (idasanutlin, RO5503781) was combined with cytarabine, the complete remission rate in patients with TP53wt AML was higher (35.6\%) than when it was given alone (NCT01773408) [44].

\section{Making mutant $\mathrm{p} 53$ functional again}

Since p53 is preferentially mutated in cancers, the treatment preventing p53 from degradation only works in cancer harboring wtp53, which limits its clinical application. Directly targeting mutp53 may have more application possibilities. However, restoring mutp53 therapeutically is more difficult than disrupting the p53-MDM2 interaction. Theoretically, the restoration of mutp53 is as follows: (1) mutp53 exhibits wild-type activity at permissive temperatures, (2) a second-site suppressor mutation can adapt to deleterious mutations and restore wild-type activities, and (3) a synthetic peptide, such as CDB3, derived from the p53-binding loop of 53BP2, can bind to the 553 core domain and rescue the DNA-binding ability of mutp53 [45-47]. The discovery of the first p53 reactivator, CP-31398, bodes well for the development of a mutp53 reactivator (Table 2). Several of 
Table 2 Compounds with the ability to reactivate mutp53

\begin{tabular}{|c|c|c|c|}
\hline Compound name & Mechanism & Mutant p53 target & References \\
\hline CP-31398 & $\begin{array}{l}\text { CP-31398 binds to the denatured DNA-binding domain of mutp53 } \\
\text { and restores nature p53 conformation }\end{array}$ & V173A, S241F, R249S, R273H & {$[155]$} \\
\hline PRIMA-1 & $\begin{array}{l}\text { PRIMA-1 enhances wtp } 53 \text { stability at } 37^{\circ} \mathrm{C} \text {, induces a conformational } \\
\text { change of mutp5 } 53 \text { and restores their DNA binding ability }\end{array}$ & $\mathrm{R} 175 \mathrm{H}, \mathrm{R} 273 \mathrm{H}$ & {$[156]$} \\
\hline APR-246 & $\begin{array}{l}\text { APR-246 enhances wtp } 53 \text { stability at } 37^{\circ} \mathrm{C} \text {, induces a conformational } \\
\text { change of mutp53 and restores their DNA binding ability }\end{array}$ & $\mathrm{R} 175 \mathrm{H}, \mathrm{R} 273 \mathrm{H}$ & [156] \\
\hline MIRA-1 & $\begin{array}{l}\text { MIRA-1 prevents unfolding of wtp53 and mutp53 and restores } \\
\text { native wtp53 conformation }\end{array}$ & $\mathrm{R} 175 \mathrm{H}, \mathrm{R} 248 \mathrm{Q}, \mathrm{R} 273 \mathrm{H}$ & [157] \\
\hline STIMA-1 & $\begin{array}{l}\text { STIMA-1 binds to the core domain of mutant p53 and results in the } \\
\text { stabilization of wtp53 conformation }\end{array}$ & $\mathrm{R} 175 \mathrm{H}, \mathrm{R} 273 \mathrm{H}$ & [158] \\
\hline PK1 1000 & PK11000 increases the Tm of mutp53 to promote correct fold & Y220C & [159] \\
\hline ZMC1 & $\begin{array}{l}\text { ZMC1 provides addition } \mathrm{Zn}^{2+} \text { to cancer with mutp53 for proper } \\
\text { folding }\end{array}$ & $\mathrm{R} 175 \mathrm{H}, \mathrm{R} 172 \mathrm{H}$ & {$[160]$} \\
\hline COTI-2 & COTI-2 converts mutp53 to wild-type form & $\mathrm{R} 175 \mathrm{H}$ & [161] \\
\hline pCAPs & pCAPs binds to the core domain of mutp53 & I195T & {$[47]$} \\
\hline Reacp53 & Reacp53 prevents mutp53 amyloid aggregation & P53 252-258 amyloid zipper structure & [162] \\
\hline RETRA & RETRA releases p73 from mutp53-p73 complex & P73 & [163] \\
\hline PK083 & $\begin{array}{l}\text { PK083 binds and stabilizes p53-Y220C to restore its transcriptional } \\
\text { activity }\end{array}$ & Y220C & [164] \\
\hline P53R3 & $\begin{array}{l}\text { P53R3 restores sequence-specific DNA-binding ability of several } \\
\text { mutp53 }\end{array}$ & $\mathrm{R} 175 \mathrm{H}, \mathrm{M} 237 \mathrm{I}, \mathrm{R} 273 \mathrm{H}$ & {$[165]$} \\
\hline SCH529074 & $\begin{array}{l}\text { SCH529074 enables mutp53 to bind to a consensus p53 DNA- } \\
\text { binding site }\end{array}$ & R175H, L194F, R248W, R249S, R273H & [166] \\
\hline PK7088 & $\begin{array}{l}\text { PK7088 selectively binds to the specific surface cavity of p } 53 \text { Y } 220 \mathrm{C} \\
\text { to destabilize it and restores wtp } 53 \text { conformation }\end{array}$ & Y220C & [167] \\
\hline Stictic acid & $\begin{array}{l}\text { Stictic acid blocks the pocket between loop L1 and sheet S3 of p53 } \\
\text { core domain and reactivates mutp53 }\end{array}$ & $\mathrm{R} 175 \mathrm{H}, \mathrm{G} 245 \mathrm{~S}$ & [168] \\
\hline Chetomin & $\begin{array}{l}\text { Chetomin promotes } \mathrm{Hsp} 40 \text { expression and the } \mathrm{p} 53-\mathrm{Hsp} 40 \text { binding } \\
\text { to restore wtp } 53 \text { conformation }\end{array}$ & $\mathrm{R} 175 \mathrm{H}$ & [169] \\
\hline RITA & RITA restores transcriptional activity of mutp53 & $\begin{array}{l}\text { I254D, R175H, R213Q, Y234H, } \\
\text { R248W/Q, R273H, R280K }\end{array}$ & [170] \\
\hline WR1065 & WR1065 restores temperature-sensitive mutp53 native conformation & V272M & [171] \\
\hline Adamantyl isothiocyanates & $\begin{array}{l}\text { Adamantyl isothiocyanates rescues mutp53 R206K and R273H and } \\
\text { results in the upregulation of canonical wtp53 targets and ATM } \\
\text { phosphorylation }\end{array}$ & $\mathrm{R} 280 \mathrm{~K}, \mathrm{R} 273 \mathrm{H}$ & [172] \\
\hline
\end{tabular}

these compounds have entered clinical trials, including APR-246 (eprenetapopt) in combination with azacytidine for myelodysplastic syndromes (MDS) with mutp53, which demonstrated a significantly higher rate of complete remission (CR) in patients with only TP53 mutation (NCT 03072043) [48].

p53 reactivators are classified in a variety of ways due to the multiple chemical classes or their overlapping roles $[14,49]$. The primary activities of p53 rescuers include: (1) stabilization of the wtp53 structure, (2) refolding or preventing misfolding of mutp53, (3) restoration of the DNA-binding ability of mutp53, and (4) promoting the expression of full-length protein from mRNAs with nonsense mutations. Although multiple p53 reactivators have been developed, only two drugs have entered clinical trials, APR-246 and COTI-2. One of the challenges in drug development stems from the p53-independent toxicities of these compounds, which may also contribute to their antitumor activity. For instance, APR-246 induces oxidative stress by converting thioredoxin reductase 1 to a NAPDH oxidase [50]. Thus, more targeted p53 reactivators are needed to minimize toxicity and improve the therapeutic window.

\section{Depletion of mutant p53}

In addition to reactivating mutp53, selective targeting of mutp53 proteins may also exhibit an antitumor effect [15]. This compound development strategy is based on the following observations: (1) depletion of mutp53 by siRNA or shRNA can suppress the mutp53-mediated malignant progression and (2) mutp53 is inherently unstable [51-53]. Therefore, the cornerstone of this strategy is to restrict the expression of mutp53 and promote the degradation of mutp53 (Table 3). 
Table 3 Compounds directly target mutp53

\begin{tabular}{|c|c|c|c|}
\hline Compound name & Mechanism & Targets & References \\
\hline Hsp90 inhibitor & $\begin{array}{l}\text { Hsp90 inhibitor prevents Hsp90 chaperone from binding } \\
\text { to mutp53 and promotes mutp53 proteins degradation }\end{array}$ & R175H, L194F, R248Q, R273H, R280K, R172H (mouse) & [173] \\
\hline HDAC inhibitor & $\begin{array}{l}\text { HDAC inhibitor inhibits HDAC-regulated transcription } \\
\text { and disrupts HDAC6/Hsp90/mutp53 complex }\end{array}$ & R175H, R280K, V247F/P223L & [56] \\
\hline Statins & $\begin{array}{l}\text { Statins inhibits the interaction between mutp } 53 \text { and } \\
\text { DNAJA1 to induce CHIP-dependent p53 degradation }\end{array}$ & V157F, R172H, R175H, Y220C, R248W, R273H, R280K & [174] \\
\hline Gambogic acid & $\begin{array}{l}\text { Gambogic acid increases wtp } 53 \text { proteins levels, inhibits } \\
\text { mutp53-Hsp90 complex and induces CHIP-mediated } \\
\text { degradation }\end{array}$ & $\mathrm{R} 175 \mathrm{H}, \mathrm{G} 266 \mathrm{E}, \mathrm{R} 273 \mathrm{H}, \mathrm{R} 280 \mathrm{~K}$ & [58] \\
\hline Spautin-1 & $\begin{array}{l}\text { Spautin-1 inhibits macroautophagy to induce mutp53 } \\
\text { degradation via chaperone-mediated autophagy }\end{array}$ & $\begin{array}{l}\text { P98S, P151H, A161T, R175C, R175D, R175H, L194F, S227K, } \\
\text { S227R, G245C, R248L, R248W, E258K, R273H, R273L, } \\
\text { R280K, and R282W }\end{array}$ & [99] \\
\hline NSC59984 & $\begin{array}{l}\text { NSC59984 promotes MDM-mediated mutp53 protein } \\
\text { degradation and stimulating p73 }\end{array}$ & R175L, R175H, S241F, R273H/P309F & [175] \\
\hline Disulfiram (DSF) & $\begin{array}{l}\text { Disulfiram catalyzes both wtp } 53 \text { and mutp } 53 \text { through } \\
\text { the } 26 S \text { proteasome pathway }\end{array}$ & $\mathrm{R} 273 \mathrm{H}$ & [176] \\
\hline
\end{tabular}

Histone deacetylase inhibitors (HDACis) are a type of antitumor agent that inhibits histone deacetylases (HDACs) and thereby regulate gene expression [54]. The expression level of mutp53 can be transcriptionally reduced by HDACis [55]. Additionally, HDACis also disrupt the HDAC6/Hsp90/mutp53 chaperone complex to destabilize mutp53 proteins and promote their degradation [56]. Targeting another mutp53 protein stabilizer, Hsp90, via an Hsp90 inhibitor, can induce apoptosis in cancers with p53 deficiency [57]. Additional compounds were discovered to be capable of promoting mutp53 degradation. For example, gambogic acid, a traditional Chinese medicine, promotes mutp53 proteasomal degradation via the chaperone-associated ubiquitin ligase carboxy terminus of Hsp70-interacting protein (CHIP) [58]. However, these agents exhibit a pan-antitumor effect apart from degrading mutp53 $[59,60]$. The act of depleting p53 within their antitumor effect should be further discussed, and the screening of agents selectively targeting mutp53 is needed.

\section{The challenges of p53-targeted therapy}

As mentioned previously, numerous strategies can be used to target wt/mutp53 in cancer therapy (Fig. 2). The MDM2/X inhibitor is effective for cancers with wtp53, which is reflected in clinical trials (Table 1). Additionally, we should recognize that directly targeting mutp53 is difficult due to the structural diversity of mutp53. It is exceedingly difficult to discover a compound that can target all mutp53. Moreover, because the p53 pathway is quite complex, and restoring p53 function in normal tissue can result in unpredictable adverse events. For instance, RG7112 is associated with at least one adverse event that is frequently associated with hematological toxicity in patients [61]. In general, strategies that directly target mutp53 require that the agents have a higher affinity for mutp53 in order to have a greater antitumor effect and fewer adverse events.

\section{Synthetic lethality with p53: a strategy that makes p53 druggable}

In comparison with p53-targeted agents, the synthetic lethal method's efficacy is less dependent on the mutp53 structure, indicating that it could be used in a broad range of conditions. Different strategies may be used depending on the mutp53 LOFs and GOFs. As mentioned previously, targeting the compensatory induced $\mathrm{G} 2$ arrest is of great interest for mutp53 LOFs. Suppressing acquired oncogenic signaling allows for the selective elimination of p53 GOF mutations. To be precise, synthetic lethal pathways involving mutp53 are numerous and vary according to the functional alteration induced by mutp53 (Fig. 3).

\section{Targeting mutp53 with cell cycle arrest}

Due to the increased reliance on intra-S and G2 arrest in cancers with mutp53, the regulators of the intra-S and G2 checkpoints (e.g., ATR, CHK1, MK2, and Wee1) have been identified [62-65]. ATR acts as a recognizer of specific single-stranded DNA sites and phosphorylates $\mathrm{CHK} 1$ to regulate the cell cycle and DNA damage response [66]. Reaper et al. first identified the synthetic lethal interaction between ATR and p53 using the selective ATR inhibitor VE-821 (Table 4) [67]. M6620 was the first ATR inhibitor to be tested in humans. The recent M6620 phase 2 clinical trial demonstrated a superior effect of M6620 and gemcitabine combination therapy (median progression-free survival, 22.9 weeks, 90\% CI 17.9-72.0 weeks) compared to gemcitabine monotherapy 


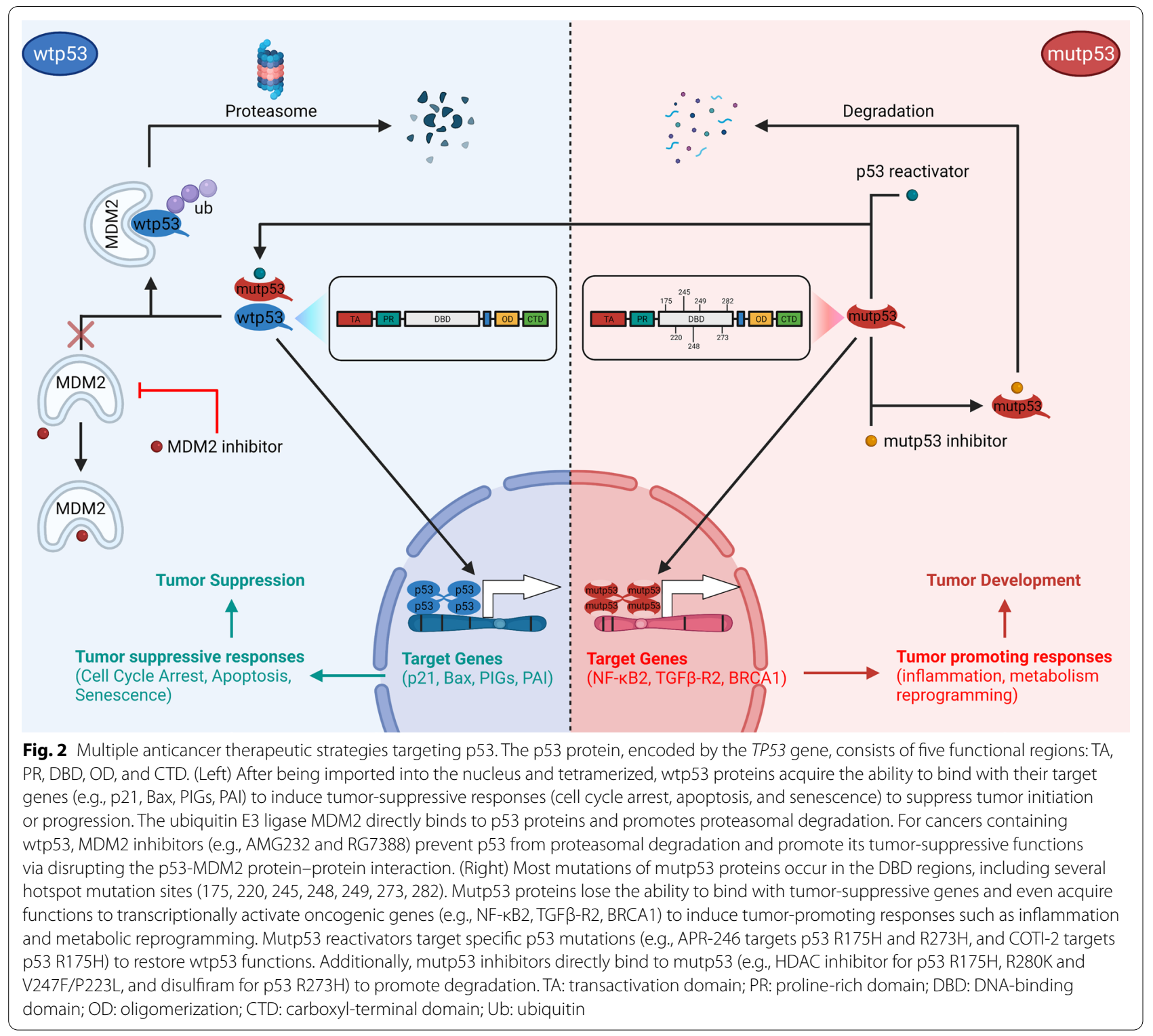

(median progression-free survival, 14.7 weeks, 90\% CI 9.7-36.7 weeks), indicating that ATR inhibitors can potentially enhance the effect of current chemotherapy $[68,69]$. Additionally, prexasertib, a CHK1 inhibitor, demonstrated antitumor activity in several high-grade serous ovarian cancer patient-derived xenograft (PDX) models [70]. Moreover, prexasertib treatment may synergize with PARP inhibition and resensitize olaparibresistant models to olaparib treatment. This result demonstrated that inhibiting G2 arrest in cancers harboring a p53 mutation has significant clinical implications. However, three clinical trials of CHK1 inhibitors (NCT01870596, NCT02797964, and NCT02797977) have been completed for ATR inhibitors compared to null. The reason may derive from the fact that ATR inhibition can result in significant defects in chromosomal segregation in normal cells, and the molecular weight of ATR is too large for compound screening $[62,71]$.

Other G2 arrest regulators may also act as mutp53 synthetic lethal partners. The p38MAPK/MK2 pathway, which regulates the $G 2 / M$ checkpoint, is activated in response to DNA damaging agents [72]. A recent study demonstrated the induction of synthetic lethality using a new cytarabine analogue, F-Se-Ara-C, that targets MK2 in prostate cancer with p53 mutation [64]. Cdc25B-mediated G2 arrest was disrupted by MK2 depletion only in p53-deficient cells, but not in wtp53-carrying cells, confirming the synthetic lethality interaction between p53 


\section{(See figure on next page.)}

Fig. 3 Synthetic lethality with mutp53 LOF and GOF. A Wtp53 maintains the survival-promoting pathways when cells undergo stress. Mutp53 loses these functions but activates compensatory pathways to protect cancer cells from lethal stresses. Thus, these compensatory pathways become vulnerable in cancers as these pathways are less dependent on normal cells. Taking the role of p53 in cell cycle arrest as an example, in response to DNA damage, wtp53 can activate p21 to induce G1 arrest to repair DNA damage (left). Under conditions of p53 mutation, cancer cells rely more on $\mathrm{S}$ and $\mathrm{G} 2$ arrest for DNA repair. Inhibition of regulators of $\mathrm{S}$ and $\mathrm{G} 2$ arrest results in the accumulation of unpaired DNA and mitotic catastrophe (right). B For mutp53 GOFs, the target genes upregulated by mutp53, which are usually silenced when p53 is not mutated, might be the crucial factors promoting tumor progression. Targeting these genes can selectively suppress the cancer progression of cancers with mutp53. Regarding energy metabolism, wtp53 inhibits glycolysis and promotes OXPHOS (left), and mutp53 acquires the opposite functions to promote glycolysis and inhibit OXPHOS (right). Herein, targeting the enhanced glycolysis induced by mutp53 can be developed for synthetic lethal approaches

and MK2 [72]. Polo-like kinase 1 (PLK1) and WEE1 are two other cell cycle regulators that have synthetic lethal interactions with p53 [65, 73]. The WEE1 kinase family is composed of three kinases: WEE1, WEE1B, and membrane-associated tyrosine- and threonine-specific cdc2-inhibitory kinase (PKMYT1) [74]. Among them, WEE1 and PKMYT1 are critical G2/M transition regulators, as the former inhibits mitotic entry by phosphorylating CDK1 on Tyr15, whereas the latter promotes mitotic entry via dual targets on Tyr15 and Thr14. [75]. MK-1775, a WEE1 inhibitor, has been discovered to have a great ability to radiosensitize human cancer cells, which only occurs in p53-deficient tumors [76]. The clinical trial on head and neck squamous cell cancer (HNSCC) using MK-1775, cisplatin, and docetaxel (NCT02508246) combined treatment validated the effectiveness and safety of this synthetic lethality between WEE1 and TP53 [77]. PLK1 is required for mitotic entry by activating CDC25 and inhibiting both WEE1 and PKMYT1 [78]. Inhibition of PLK1 by BI2536 significantly suppresses cells with p53 mutation [73]. However, the PLK1 inhibitor BI2536 had a low response rate and induced severe adverse effects in patients resulting in poor efficacy [79]. The reason might be associated with the multiple roles of PLK1 in addition to regulating the $\mathrm{G} 2 / \mathrm{M}$ checkpoint, including centrosome coordination, regulating chromosome segregation, and facilitating DNA replication [78]. The distinct outcomes of targeting regulators during G2 arrest suggest that a greater understanding of mutp 53 and the G2 arrest is required and that more selective regulators are preferable candidates.

\section{Targeting mutp53 with energy metabolism}

The involvement of p53 in glycolysis and oxidative phosphorylation (OXPHOS) is well recognized [80]. p53 suppresses glycolysis by inhibiting multiple regulators in the glycolytic pathway. For example, p53 can limit glucose uptake by inhibiting the expression of glucose transporter 1/4 (GLUT1/4) directly or GLUT3 indirectly via the IKK $\beta / N F-\kappa B / G L U T 3$ pathway $[81,82]$. p53 stimulates OXPHOS via multiple pathways, including transactivating cytochrome c oxidase $2(\mathrm{SCO} 2)$ to maintain cytochrome c oxidase assembly and upregulating apoptosis-inducing factor $(A I F)$ to maintain mitochondrial complex I integrity [83, 84]. Reprogramming of energy metabolism from OXPHOS to glycolysis even under aerobic conditions (Warburg metabolism) is one of the hallmarks of cancer [85]. The majority of mutant p53 loses its ability to maintain metabolic homeostasis and even acquires additional functions to promote Warburg metabolism. Based on this phenomenon, combining synthetic lethality with energy metabolism is extremely appealing.

Glucose uptake is the first rate-limiting step of glycolysis. Compared to the suppressive effect of p53 on GLUT, mutp53 promotes GLUT expression by augmenting glucose uptake in cancer cells [86]. For instance, Zhang and colleagues discovered that lung cancer cells expressing $\mathrm{R} 175 \mathrm{H}, \mathrm{R} 248 \mathrm{Q}$, and $\mathrm{R} 273 \mathrm{H}$ mutant $\mathrm{p} 53$ exhibited an enhanced Warburg effect via activation of the RhoA/ ROCK pathway, thereby increasing GLUT1 expression and membrane localization [86]. Inhibition of GLUT and RhoA suppressed tumor progression, but targeting RhoA was more tumor-specific as it only impacted mutp53mediated glycolysis, which had less effect on normal cells. Hexokinase-II (HK2), the first rate-limiting enzyme of glycolysis, was transcriptionally downregulated by wtp 53 , and its mRNA level was also reduced by wtp53 [87, 88]. p53 deficiency enables the upregulation of HK2, and HK2 knockdown significantly reduces cancer cell proliferation [88]. However, HK2 also maintains glycolysis in normal cells, which leads to the perplexity of inhibiting HK2 for cancer therapy. Additionally, Emerling et al. found a synthetic lethal relationship between type 2 PIP kinase genes (PIP4K2B) and p53 mutation/deletion [89]. Under the context of p53 loss, phosphatidylinositol-5-phosphate 4-kinase $\beta$ (PI5P4K $\beta$, encoded by PIP4K2B) plays a crucial role in maintaining glucose metabolism and reactive oxygen species (ROS) homeostasis. The functions of PI5P4K $\beta$ were unnecessary in a cell line with wtp53. In addition to the factors regulating glycolysis, mutp53 also regulates glycolysis indirectly by ncRNAs. For example, lncRNA AGPG is negatively transcriptionally regulated by $\mathrm{p} 53$, which regulates glycolysis by binding to 


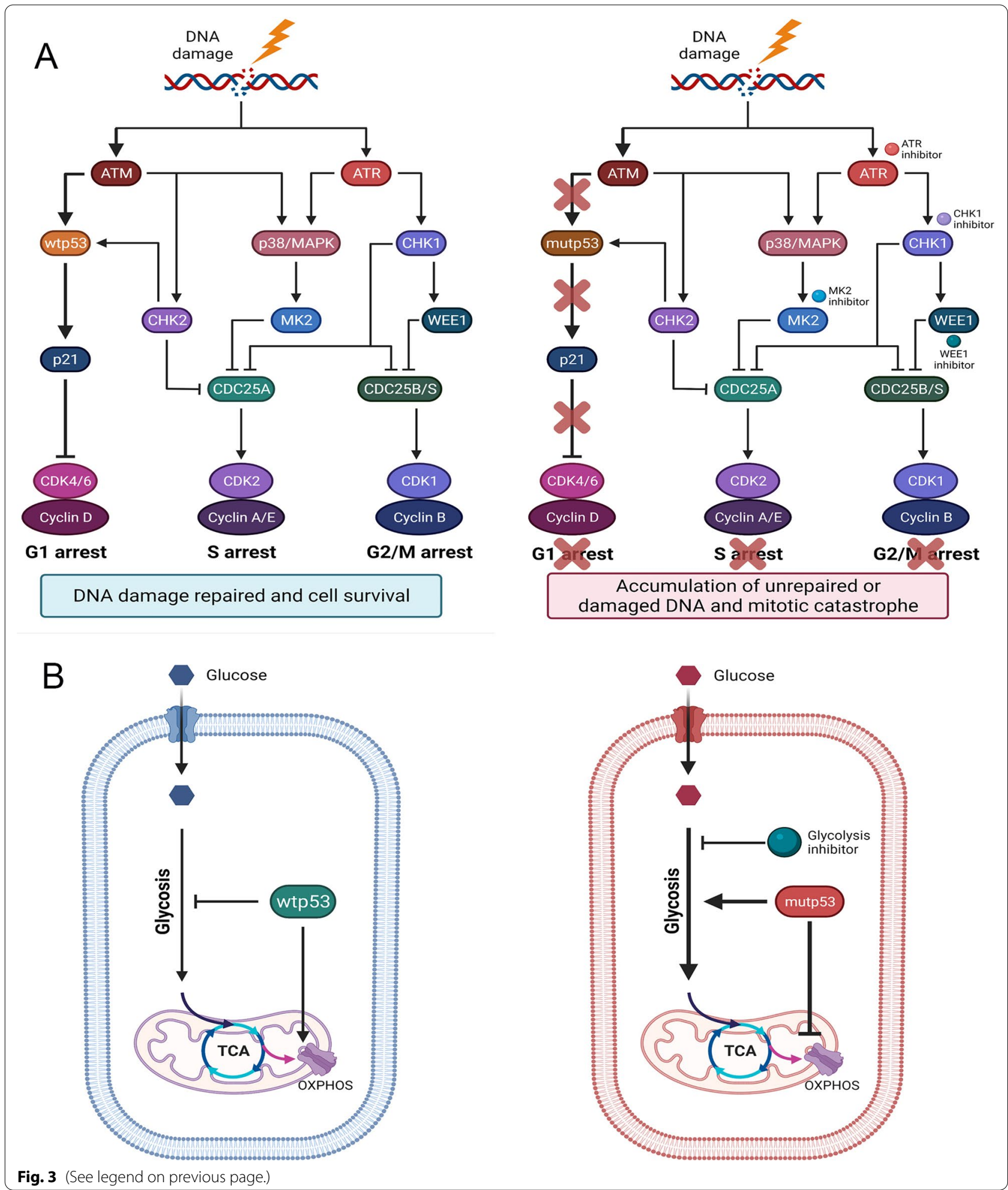

and stabilizing phosphofructo-2-kinase/fructose-2,6-biphosphatase 3 (PFKFB3), a rate-limiting enzyme in glycolysis [90]. However, mutp53 loses this transcription suppressive function, leading to the upregulation of AGPG and promotes glycolysis for cancer progression. This phenomenon indicated that targeting ncRNAs may 
Table 4 Synthetic lethal partners with mutp53

\begin{tabular}{|c|c|c|}
\hline Synthetic lethal partner & Mechanism & References \\
\hline ATR & ATR inhibitors target ATR/CHK1 pathway to suppress G2 arrest in p53-deficient cancers & {$[68,69,177]$} \\
\hline CHK1 & CHK1 inhibitors target CHK1 to suppress G2 arrest in p53-deficient cancers & [70] \\
\hline p38MAPKMMK2 & $\begin{array}{l}\text { MK2 regulates of G2/M and S-phase checkpoint in p53-mutated/p53-deficient cancers in response to DNA } \\
\text { damage }\end{array}$ & {$[64,72]$} \\
\hline WEE1 & WEE1 plays a crucial role in the G2/M transition for p53-mutated cancers & {$[76,77]$} \\
\hline PLK1 & PLK1 is required for mitosis entry by activating CDC25 and inhibiting both WEE1 and PKMYT1 & {$[73,79]$} \\
\hline PIP4K2B & $\begin{array}{l}\text { High level of PI5P4Ks promotes glucose uptake to support glucose metabolism and enhances NADPH gen- } \\
\text { eration to mediated ROS response in the condition of p53 mutation/deletion }\end{array}$ & [89] \\
\hline HK2 & $\begin{array}{l}\text { HK2 regulates the transform from phosphorylating glucose into glucose-6-phosphate to elevate glycolysis for } \\
\text { glycolysis }\end{array}$ & {$[88,178]$} \\
\hline mTOR & mTOR-induced inhibition of autophagy prevents mutp53 proteins from autophagy-mediated degradation & [96] \\
\hline PDGFR $\beta$ & PDGFR $\beta$ maintains the premetastatic phenotype for pancreatic ductal adenocarcinoma with p53 R172H & [103] \\
\hline PLA2G16 & Mutp53 binds to the promoter of PLA2G16 to promote metastatic phenotype & [104] \\
\hline
\end{tabular}

also induce synthetic lethality in p53-mutated cancers. Taken together, both altered energy metabolism induced by oncogenic mutp53 GOFs and compensatory activated signaling for p53 LOFs were viable synthetic lethal strategies in the presence of p53 mutation.

Although mutp53 preferentially exhibits glycolysispromoting functions, several cancer cells with mutp53 display enhanced mitochondrial functions. Eriksson et al. found that $\mathrm{H} 1299$ cells induced with p53 R175H and $\mathrm{R} 273 \mathrm{H}$ showed enhanced mitochondrial respiration capacity [91]. This finding suggested the possibility of targeting OXPHOS for cancer therapy with mutp53. Additionally, inhibiting OXPHOS could be regarded as a combination regimen with glycolysis inhibitors. This approach showed feasibility, as cotreatment with 2-deoxyglucose (glycolytic inhibitor) and metformin (OXPHOS inhibitor), had a significant effect on prostate cancer cells compared to monotherapy [92]. However, in our opinion, targeting OXPHOS might be a riskier strategy as OXPHOS is the major energy resource of normal cells. Moreover, Warburg metabolism is a common metabolic alteration in cancer cells instead of an advantage of cancers with p53 mutations. Herein, screening synthetic lethal partners with mutp53 in the field of energy metabolism should integrate the specific genetic alteration of mutp53.

\section{Other potential synthetic lethal pathways with mutp53 Targeting mutp53 with autophagy}

Autophagy is a housekeeping process that controls protein and organelle quality and recycles intracellular components such as misfolded proteins and dysfunctional mitochondria as alternative resources to maintain normal biological activities, particularly under conditions of nutritional deprivation [93]. In tumors, autophagy has a dual effect: it inhibits tumor formation while also promoting tumor growth once it has begun [94]. Autophagy is thought to be suppressed by mutp53. Several recent studies have identified that mutp53 R175H, R273H, and R273L can inhibit autophagy by blocking AMPK, activating mTOR, and stabilizing HIF-1 proteins [95]. Additionally, mutp53 represses the NF-kB-mediated expression of atg12 to impact autophagy by interacting with the p50 NF-кB subunit [96].

Autophagy inhibition can be viewed as a p53 GOF that promotes tumor progression by reducing mutp53 degradation via the autophagy pathway [97]. The canonical AMPK/mTOR pathway is regarded as the core signaling cascade of mutp53-mediated suppression of autophagy [98]. Pharmacological induction of autophagy by mTOR inhibition or AMPK activation has been shown to have potential therapeutic value, and the activation of autophagy induced by mutp53 makes cancer cells more sensitive to the mTOR inhibitor everolimus, especially in cancers with p53 mutations [96]. Inhibiting mTOR to induce autophagy may be a potential synthetic lethal approach to mutp53 as mTOR is usually activated in cancer cells. Several strategies to deplete mutp53 also rely on autophagy; for example, spautin-1 promotes chaperone-mediated autophagy to degrade mutp53 [99]. As autophagy initiation is quite complicated, we can hypothesize that drugs that affect the autophagy process rather than its constituents are synthetically lethal for cancers with p53 mutations.

\section{Targeting mutp53 activated invasion and metastasis}

Although exploiting the strategies to selectively kill tumor cells with mutp53 is appealing, targeting mutp53-activated invasion and metastasis to suppress tumor progression is also attractive. Mutp53 has been demonstrated to 
have metastatic potential by promoting epithelial-mesenchymal transition (EMT), altering the extracellular matrix (ECM), and inhibiting its binding partner p63/p73 to indirectly modulate the genes that control metastasis and invasion [100-102]. Mutp53 can facilitate invasion by increasing receptor expression and activating downstream signaling pathways, similar to how TP53 R175H and $\mathrm{R} 273 \mathrm{H}$ promote metastasis via EGFR recycling. It is plausible that metastatic cancers in their advanced stages rely on mutp53-mediated invasion and metastasis.

A murine model study revealed that sustaining the premetastatic phenotype of pancreatic ductal adenocarcinoma (PADC) requires sustained expression of p53 $\mathrm{R} 172 \mathrm{H}$, which increases platelet-derived growth factor beta (PDGFR), and inhibition of PDGFR with imatinib significantly prevents PDAC metastasis in vivo [103]. Another study in a murine model found that PLA2G16, a phospholipase that can catalyze phosphatidic acid into metastasis-promoting lysophosphatidic acid and free fatty acid, was upregulated in p53 R172H mutant osteosarcomas by binding to its promoter at E26 transformation-specific binding motifs [104]. Knockdown of PLA2G16 or ETS specifically weakens the metastatic potential of cancer [104].

\section{Noncoding RNAs: expanding the potential synthetic lethality network of p53}

Genes encoding proteins account for only $1-2 \%$ of the human genome, leaving numerous ncRNAs to be exploited for cancer therapy [23]. ncRNAs can be classified into two types based on size: small RNAs such as microRNAs (miRNAs) and long noncoding RNAs (lncRNAs) at least 200 nucleotides in length [105]. Over the last few decades, researchers have discovered that ncRNAs participate in various cellular and molecular mechanisms, such as the regulation of gene expression, chromatin modification, and lncRNA-protein interactions [23, 106, 107]. p53 also plays an important role in the regulation of ncRNAs including miRNAs and lncRNAs [108-110]. Mutation of p53 could lead to a dysregulated wtp53/ncRNA network and active mutp53mediated ncRNA alteration. Therefore, the development of a synthetic lethal approach with mutp53 is theoretically feasible in the field of ncRNAs.

\section{Mutp53 and microRNAs}

The most prevalent and well-studied small ncRNA type are miRNAs, which have a length of approximately $20 \mathrm{nt}$ [111]. The major functions of miRNAs are typically associated with inhibiting the translation or promoting the degradation of their target mRNAs [106]. Thus, altered miRNA levels can further influence protein concentrations via a posttranscriptional mechanism. Wtp53 can regulate miRNA levels by directly activating transcription or promoting maturation [112]. In contrast, p53 GOF mutations result in the dysregulation of the wtp53/ miRNA axis and upregulation of the expression of other miRNAs to confer additional oncogenic abilities, such as metastasis and somatic cell reprogramming [113, 114]. Moreover, several studies have recently focused on circulating miRNAs to explore their diagnostic and prognostic potential, indicating the potential clinical application of miRNAs [115]. Therefore, targeting mutp53-specific miRNAs may become an effective approach for cancer therapy.

The miR-34 family is composed of three members miR$34 \mathrm{a}$ and $\mathrm{miR}-34 \mathrm{~b} / \mathrm{c}$, which are the first reported miRNAs directly regulated by p53 [116]. The activation of p53 upregulates miR-34 expression, which is synergistic with the antitumor effect of p53. It has been well demonstrated that miR-34 expression levels are lower in cancer tissues than in normal tissues, such as intestinal, breast, and lung cancers [117-119]. Thus, miR-34a is an appropriate target for cancer therapy. For example, Park et al. found low expression of miR-34a in MCF7/ADR cells, and ectopic expression of miR-34a significantly suppresses tumor growth by inhibiting Notch1 [118]. MiRNAs as cancer therapeutic targets are now possible due to the development of miRNA delivery systems that utilize viral or nonviral vectors [120]. In phase I clinical trial using MRX34, the application of a miRNA-associated therapeutic drug was first explored (NCT01829971) [121]. However, due to the severity of immune-mediated adverse events, this study was halted. One reason for this may be due to MRX34's on-target effect in normal tissues, which results in an induced miR-34a-mediated response. Even though the study was unsuccessful, it established a proof of concept for miRNA-based therapy.

In addition to targeting miRNAs dysregulated by loss of wild-type p53 functions, targeting mutp53-mediated miRNAs is also attractive. As is the case with the miRNAs summarized in Table 5 , miRNAs mediated by mutp53 have been linked to tumor progression. Luo et al. found that p53-targeted miR-223-3p expression was decreased in p53-mutated lung cancers because mutp53 could bind to the miR-223-3p promoter and inhibit its expression [122, 123]. However, miR-223-3p acted as a tumor suppressor via the miR-223-5p-mutp53 feedback loop, because mutp53 was a target of miR-223-3p [123]. Treatment with the miR-223-3p agomir significantly suppressed the progression of lung cancer in vivo. Numerous studies have established the tumor-suppressive properties of miR-223-3p, and based on this study, we are convinced that miR-223-3p is a component of synthetic lethality to mutp53. 
Table 5 Noncoding RNAs regulated by mutp53

\begin{tabular}{|c|c|c|c|}
\hline Target & Mechanism & Cancer type & References \\
\hline miR-130b & miR-130b promotes EMT by ZEB1 & Endometrial cancer & [179] \\
\hline miR-30d & miR-30d impacts on the sector to promote ECM for metastasis & Breast cancer & [124] \\
\hline $\mathrm{miR}-21-3 p / \mathrm{miR}-769-3 p$ & p53 R273H activates fibroblasts by exosomal miR-21-3p & Lung cancer & [113] \\
\hline miR-1246 & $\begin{array}{l}\text { Cancers with mutp53 shed exosomes containing miR-1246 induce a } \\
\text { miR-1246-dependent reprogram of TAMs to a tumor-suppurative status }\end{array}$ & Colon cancer & [180] \\
\hline miR-34 & $\begin{array}{l}\text { This tumor-suppressive miRNA is usually downregulated in p53-mutated } \\
\text { cancers }\end{array}$ & Multiple cancers & {$[117,181]$} \\
\hline miR-223-3p & $\begin{array}{l}\text { Mutp53 directly binds to the promoter region of miR-223-3p that can } \\
\text { suppress tumor proliferation and migration }\end{array}$ & Lung cancer & [123] \\
\hline miR-200 & miR-200 suppressed by mutp53 losses the ability to inhibit metastasis & NSCLC & [182] \\
\hline Let-7i & $\begin{array}{l}\text { let-7i inhibits invasion and metastasis by repressing E2F5, LIN28B, MYC, } \\
\text { and NRAS }\end{array}$ & Breast cancer & [52] \\
\hline miR-142-3p & $\begin{array}{l}\text { Upregulation of Dnmt1 promotes miR-142-3p hypermethylation of its } \\
\text { locus }\end{array}$ & Pancreatic ductal adenocarcinoma & [183] \\
\hline LincRNA-p21 & $\begin{array}{l}\text { LincRNA-p21 cannot be activated by mutp53 in response to DNA dam- } \\
\text { age }\end{array}$ & HNSCC & [137] \\
\hline AGPG & $\begin{array}{l}\text { p53 mutations lose the transcriptionally suppress function to inhibit } \\
\text { AGPG expression, and upregulated AGPG stabilizes PFKFB3 to promote } \\
\text { glycolysis }\end{array}$ & Esophageal squamous cell carcinoma & [90] \\
\hline MALAT1 & $\begin{array}{l}\text { MALAT1 acts as a bridge between mutp53 and ID4 to modulate VEGFA } \\
\text { isoforms expression }\end{array}$ & Breast cancer & [138] \\
\hline Lnc273-31/34 & $\begin{array}{l}\text { p53 R273H specific upregulates Inc273-31 to maintain self-renew of } \\
\text { colorectal CSCs }\end{array}$ & Colorectal cancer & [184] \\
\hline IncMIR205HG & $\begin{array}{l}\text { Mutp53 recruited by NF-YA and E2F1 to the promoter of MIR205HG to } \\
\text { upregulate IncMIR205HG to promote cancer progression }\end{array}$ & HNSCC & [185] \\
\hline LINC00460 & $\begin{array}{l}\text { Upregulation of LINC00460 by mutp } 53 \text { increases mutp } 53 \text { levels through } \\
\text { competitively binding to miRNAs targeting mutp } 53\end{array}$ & Colorectal cancer & [186] \\
\hline CircPVT1 & $\begin{array}{l}\text { CircPVT1 is upregulated by mutp } 53 \text { in HNSCC patients to promote } \\
\text { cancer proliferation by miR-497-5p }\end{array}$ & HNSCC & [187] \\
\hline Circ-CCNB1 & $\begin{array}{l}\text { Circ-CCNB1 is suppressed in p53-mutated cancer, and expression of circ- } \\
\text { CCNB1 activates the H2AX-dependent tumor suppressor Bclaf1 only in } \\
\text { cancer cells harboring mutp53 }\end{array}$ & Breast cancer & [140] \\
\hline
\end{tabular}

Mutp53 can also upregulate multiple oncogenic miRNAs to promote tumor progression. For example, mutp53 can induce the expression of miR-30d, which causes tubule vesiculation of the Golgi apparatus to enhance vesicular trafficking and secretion to promote metastasis [124]. Additionally, mutp53 boosts the release of miR-1246 into tumor stroma to support the formation of tumor-associated macrophages [125]. Targeting these mutp53-associated miRNAs can suppress tumor growth.

\section{Mutp53 with long noncoding RNAs and circRNAs}

Compared to miRNAs, the characterizations and functions of lncRNAs, which are cell-type specific, are more complex. Although over 60,000 distinct lncRNAs have been predicted based on initiatives and databases such as ENCODE, GENCODE, LNCipedia, and lncRNome, the majority of these lncRNAs still need to be studied and annotated [126-129]. LncRNAs are categorized into four types according to their functions: signals, decoys, guides, and scaffolds $[130,131]$. The structural flexibility of lncRNAs allows them to interact with DNA, RNA, or proteins via base pairing [130]. As an example of transcriptional regulation, a sequence-specific mature lncRNA transcript can have a direct effect on the expression of its adjacent genes, as demonstrated by the positive and negative regulation of $\mathrm{X}$-chromosome inactivation by lncRNA Tsix and its antisense counterpart Xist. On the other hand, lncRNAs indirectly regulate transcription by decoying or guiding regulatory proteins. For example, the long noncoding RNA Gas5 acts as a decoy for DNA receptors, preventing metabolic genes from being transcribed. Additionally, lncRNA ANRIL directs polycomb repressive complexes 1 and 2 (PRC1 and 2) to regulate cell cycle-related gene expression. A scaffold function has been demonstrated by the finding that GClnc1 binds WDR5 and KAT2A histone acetyltransferases, thereby specifying the histone modification of mitochondrial superoxide dismutase 2 [132-135].

As a well-studied transcription factor, p53 also regulates the expression of lncRNAs to compose the p53 
signaling network. It is reasonable that tumor-associated lncRNAs induced by p53 mutation can be exploited for cancer therapy. LincRNA-p21, which acts as a repressor of the p53 pathway and cannot normally be induced by mutp53 in response to DNA damage, was the first identified lncRNA transcriptionally induced by p53 [136]. A recent study conducted by Jin et al. showed that lincRNA-p 21 can also be regulated by mutant p53 in cooperation with nuclear transcription Factor $\mathrm{Y}$ subunit $\alpha$ (NF-YA) to block JAK/STAT3 signaling to suppress tumor progression [137]. It is reasonable to be concerned that increasing the interaction between mutp53 and NF-YA may inhibit tumor progression in mutp53-positive cells via upregulation of lincRNA-p21. Apart from directly regulating the expression of lncRNAs, mutp53 can also modulate the expression of tumor promoter factors by cooperating with lncRNAs. MALAT1 is a lncRNA that regulates serine-/arginine-rich (SR) proteins in the nucleus and interacts with mutp53, IDH4, and SRSF1 to form a complex to promote VEGFA expression in breast cancer [138]. This complex does not exist in the presence of wtp53. Targeting the mutp53/IDH4/SRSF1/MALAT1 complex may provide a new therapeutic approach for mutp53 breast cancers.

CircRNA is a type of noncoding RNA that connects its 3' and 5' ends via "backsplicing" to form a singlestranded loop structure that is resistant to exonuclease-mediated degradation [139]. CircRNAs function as miRNA or RNA-binding protein (RBP) sponges to regulate gene expression or as scaffolds to aid protein complex assembly, interact with proteins to enhance their functions, and they can even be translated into peptides themselves [139]. Circ-Ccnb1 is downregulated in breast cancer and has tumor-inhibitory properties [140]. Surprisingly, ectopic expression of circ-Ccnb1 reduced proliferation only in cancers harboring mutp53. The interaction between circ-Ccnb1, wt/mutp53, H2AX, and Bclaf1 is thought to be the mechanism underlying this phenomenon. H2AX acts as a bridge for circ-CCnb1 to bind wtp53 or Bclaf1, but H2AX binds wtp53 more strongly. Increased circ-Ccnb1 binding increases wtp53 binding in p53 wild-type cells, thereby inhibiting the H2AX-dependent tumor-suppressor Bclaf1 from inducing apoptosis. Mutp53, on the other hand, is unable to bind to H2AX, resulting in Bclaf1-H2AX binding and apoptosis-inducing the proliferation of cancer cells. This interaction demonstrates the possibility of targeting circCcnb1 to selectively kill cancer cells using mutp53 while sparing normal tissues.

Several approaches can be adopted to modulate lncRNAs: (1) employing promoter-targeted duplex RNAs to increase the expression of lncRNAs whose transcripts overlap gene promoters; (2) inhibiting lncRNA levels using antisense oligonucleotide (ASO) or siRNAmediated knockdown; and (3) preventing the binding of lncRNAs to DNA, RNA, or proteins by utilizing small molecules/peptides [141]. However, no lncRNA drugs have entered clinical trials. The difficulties stem from the poor conservation of $\operatorname{lncRNAs}$ and the transferability of lncRNA studies from mouse models to humans.

\section{Future perspectives of mutp53-targeted cancer therapy}

Due to the high frequency of p53 mutations, it is an appealing target for therapeutic strategies. The most convenient strategy is to directly target $\mathrm{p} 53$. In cancers where p53 is intact, inhibiting its negative regulator MDM2/X can activate the native tumor-suppressive function of p53. However, a significant limitation of this approach is the adverse event caused by widespread wtp 53 activation in normal tissues [61]. It is preferable to develop a drug delivery system capable of transporting drugs specifically into tumors. For instance, nanomedicine-based therapy can significantly enhance drug efficacy while minimizing adverse effects [142]. Moreover, MDM2 inhibitor monotherapy is insufficient to completely suppress tumor progression. Thus, exploring a combination regimen of MDM2 inhibitors with other treatments may be a prospect for anticancer strategies [143]. For the strategies to reactive or deplete mutations, challenges arise from the determination of mutp53 protein structure [144]. Multiple p53 mutations necessitate the use of multiple agents directed against mutp53, let alone the specific and effective functions of the mutp53 reactivator/inhibitor.

In comparison with directly targeting p53, a synthetic lethal approach may be more widely used. As previously stated, p53 mutations are prevalent in a variety of cancer types [6]. LOFs derived from mutp53 activate alternative pathways that are compensatory for wtp53's survivalpromoting functions, which are vulnerabilities of mutp53 that can be exploited for cancer therapy. Appropriate approaches, such as model organisms, yeast, RNAi, CRISPR, and genetic network screens, are required to make synthetic lethality to p53 mutations a viable option [17]. However, mutp53 acquires oncogenic functions to stimulate multiple signaling pathways to promote tumor progression, which also increases the difficulty of screening potential synthetic lethal partners. Additionally, with increasing studies on the functions of ncRNAs, the importance of exploiting synthetic lethality with mutp53 and ncRNA networks should be mentioned [145]. Wtp53 can regulate miRNA expression via transcriptional or posttranscriptional methods, which supports the theory of screening synthetic lethal partners within miRNAs [108]. While multiple studies have established a link between lncRNAs and circRNAs and mutp53, it should 
be determined whether the relationships between ncRNAs and mutp53 can be expanded to pan-cancer studies. More studies with compelling evidence focusing on lncRNAs and circRNAs will identify additional synthetic lethality partners of mutp53.

In general, we have a variety of strategies for cancer therapy that target $w t / m u t p 53$. Due to the prevalence of p53 mutations in cancer cells, we believe that a more precise classification of mutp53 is required to be consistent with the associated therapeutic strategies. Using mutp53 as an example, p53 LOF mutations can be classified according to their functional alteration, such as deficiency in cell cycle arrest or acquired oncogenic functions to promote glycolysis. Thus, therapeutic targets and relevant agents can be classified differently.

\section{Conclusions}

As an important but highly mutated tumor-suppressive gene, p53 is an attractive therapeutic target for cancer therapy. Reactivating the functions of tumor-suppressive factors is more challenging than directly inhibiting oncogenic factors. Direct targeting of the mutp53 protein is highly dependent on the unique structures of the protein, which makes drug development more complex and limits the applications of drugs. The indirect strategy, which is based on the concept of synthetic lethality, targets the unique vulnerabilities or alterations caused by mutp53 functional defects or acquired oncogenic functions. The synthetic lethality-based approach targeting mutp53, such as utilizing PARP inhibitors to treat cancers harboring BRCA1/2 mutations, can kill tumors with mutp53 while having no or little negative effects on normal cells or tissues. The development of synthetic lethality strategies with mutp53 can bring extensive benefits to patients. Due to the shortcomings in the G1 arrest of TP53mutated malignancies, current studies focus on the suppression of G2 arrest. However, more studies should be conducted to improve the efficacy of monotherapy, limit the side effects of combination therapies, and expand the repertoire of mutp53 synthetic lethal partners. Based on the research of ncRNAs in cancer, it is reasonable to investigate ncRNAs for synthetic lethality. Although the use of ncRNAs as therapeutic targets for cancer is still in its early stages, it has the potential to expand and fulfil the synthetic lethal network of mutp53. In general, TP53 is an attractive therapeutic target for cancer, and the development of synthetic lethality with mutp53 will considerably expand clinical options for cancer patients. Furthermore, as more treatments targeting p53 are being developed, it will be feasible to design personalized treatment plans according to the p53 mutation of patients.

\section{Abbreviations}

MDM2/X: mouse double minute 2/X; LOFs: loss of functions; GOFs: gain of functions; DBD: DNA-binding domain; wtp53: wild-type p53; mutp53: mutant p53; RS: replication stress; ncRNAs: noncoding RNAs; TCGA: The Cancer Genome Atlas; MDS: myelodysplastic syndromes; CR: complete remission; HDACi: histone deacetylase inhibitor; HDACs: histone deacetylases; CHIP: chaperone-associated ubiquitin ligase carboxy terminus of Hsp70-interacting protein; PDX: patient-derived xenograft; PLK1: polo-like kinase 1; PKMYT1: membrane-associated tyrosine- and threonine-specific cdc2-inhibitory kinase; HNSCC: head and neck squamous cell cancer; OXPHOS: oxidative phosphorylation; GLUT1/4: glucose transporter 1/4; SCO2: cytochrome c oxidase 2; AIF: apoptosis-inducing factor; HK2: hexokinase-II; PIP4K2B: PIP kinase genes; PI5P4K $\beta$ : phosphatidylinositol-5-phosphate 4-kinase $\beta$; ROS: reactive oxygen species; PFKFB3: 6-phosphofructo-2-kinase/fructose-2,6-biphosphatase 3; EMT: epithelial-mesenchymal transition; ECM: extracellular matrix; PADC: pancreatic ductal adenocarcinoma; PDGFR: platelet-derived growth factor beta; miRNAs: microRNAs; IncRNAs: long noncoding RNAs; PRC: polycomb repressive complex; NF-YA: nuclear transcription factor Y subunit a; SR: serine-/ arginine-rich; RBP: RNA-binding protein; ASO: antisense oligonucleotide.

\section{Acknowledgements}

We would like to thank all the authors of the primary studies. Additionally, we appreciate Suparat Tongpeng, Ziyi Lu, Tian'en Chen and Cheeshin Lee for all the assistance they contributed in this study. The figures in this article were created using Adobe Illustrator, Adobe Photoshop, BioRender, and Microsoft PowerPoint.

\section{Authors' contributions}

$J H, J C, W T, S J$ and MC wrote this paper. SL, BZ, LC and XC reviewed this paper. All authors read and approved the final manuscript.

\section{Funding}

This work was supported by the Opening Fund of Engineering Research Center of Cognitive Healthcare of Zhejiang Province (Grant Number No.2018KFJJ09), Scientific Research Fund of Zhejiang Provincial Education Department (Grant Number Y201941406), National Natural Science Foundation of China (Grant Numbers No.81827804 and N0.81800540), and Key Research and Development Project of Zhejiang Province (No. 2018C03083).

Availability of data and materials

Not applicable.

\section{Declarations}

Ethics approval and consent to participate Not applicable.

Consent for publication

Not applicable.

Competing interests

All the authors declare no conflict of interests.

\section{Author details}

${ }^{1}$ Department of General Surgery, Sir Run-Run Shaw Hospital, Zhejiang University, No. 3 East Qingchun Road, Hangzhou 310016, China. ${ }^{2}$ School of Medicine, Zhejiang University, Hangzhou 310058, China. ${ }^{3}$ Engineering Research Center of Cognitive Healthcare of Zhejiang Province, Zhejiang Province, Hangzhou, China. ${ }^{4}$ Key Laboratory of Endoscopic Technique Research of Zhejiang Province, No. 3 East Qingchun Road, Hangzhou 310016, China.

Received: 22 June 2021 Accepted: 13 September 2021

Published online: 28 September 2021

References

1. Levine AJ. p53, the cellular gatekeeper for growth and division. Cell. 1997;88:323-31. 
2. Kastenhuber ER, Lowe SW. Putting p53 in context. Cell. 2017;170:1062-78.

3. Karni-Schmidt O, Lokshin M, Prives C. The roles of MDM2 and MDMX in cancer. Annu Rev Pathol. 2016;1 1:617-44.

4. Kruiswijk F, Labuschagne CF, Vousden KH. p53 in survival, death and metabolic health: a lifeguard with a licence to kill. Nat Rev Mol Cell Biol. 2015:16:393-405.

5. Sabapathy K, Lane DP. Therapeutic targeting of p53: all mutants are equal, but some mutants are more equal than others. Nat Rev Clin Oncol. 2018;15:13-30.

6. Olivier M, Hollstein M, Hainaut P. TP53 mutations in human cancers: origins, consequences, and clinical use. Cold Spring Harb Perspect Biol. 2010:2:a001008.

7. Kotler E, Shani O, Goldfeld G, Lotan-Pompan M, Tarcic O, Gershoni A, Hopf TA, Marks DS, Oren M, Segal E. A systematic p53 mutation library links differential functional impact to cancer mutation pattern and evolutionary conservation. Mol cell. 2018;71:178-90.

8. Zhou X, Hao Q, Lu H. Mutant p53 in cancer therapy-the barrier or the path. J Mol Cell Biol. 2019;11:293-305.

9. Stiewe T, Haran TE. How mutations shape p53 interactions with the genome to promote tumorigenesis and drug resistance. Drug Resist Updates Rev Comment Antimicrob Anticancer Chemother. 2018;38:27-43.

10. Liu $Y$, Wang $X$, Wang $G$, Yang $Y$, Yuan $Y$, Ouyang L. The past, present and future of potential small-molecule drugs targeting p53-MDM2/MDMX for cancer therapy. Eur J Med Chem. 2019;176:92-104.

11. Parrales A, Iwakuma T. Targeting oncogenic mutant p53 for cancer therapy. Front Oncol. 2015;5:288.

12. Vassilev LT, Vu BT, Graves B, Carvajal D, Podlaski F, Filipovic Z, Kong N, Kammlott U, Lukacs C, Klein C, et al. In vivo activation of the p53 pathway by small-molecule antagonists of MDM2. Science (New York, NY). 2004;303:844-8

13. Shangary S, Wang S. Small-molecule inhibitors of the MDM2-p53 protein-protein interaction to reactivate $\mathrm{p} 53$ function: a novel approach for cancer therapy. Annu Rev Pharmacol Toxicol. 2009:49:223-41.

14. Bykov VJN, Eriksson SE, Bianchi J, Wiman KG. Targeting mutant p53 for efficient cancer therapy. Nat Rev Cancer. 2018;18:89-102.

15. Schulz-Heddergott R, Moll UM. Gain-of-function (GOF) mutant p53 as actionable therapeutic target. Cancers. 2018;10:188.

16. Mateo J, Lord CJ, Serra V, Tutt A, Balmaña J, Castroviejo-Bermejo M, Cruz C, Oaknin A, Kaye SB, de Bono JS. A decade of clinical development of PARP inhibitors in perspective. Ann Oncol Off J Eur Soc Med Oncol. 2019;30:1437-47.

17. O'Neil NJ, Bailey ML, Hieter P. Synthetic lethality and cancer. Nat Rev Genet. 2017;18:613-23.

18. McLornan DP, List A, Mufti GJ. Applying synthetic lethality for the selective targeting of cancer. N Engl J Med. 2014;371:1725-35.

19. Chen J. The cell-cycle arrest and apoptotic functions of p53 in tumor initiation and progression. Cold Spring Harb Perspect Med. 2016;6:a026104

20. Sancar A, Lindsey-Boltz LA, Unsal-Kaçmaz K, Linn S. Molecular mechanisms of mammalian DNA repair and the DNA damage checkpoints. Annu Rev Biochem. 2004:73:39-85.

21. Denisenko TV, Sorokina IV, Gogvadze V, Zhivotovsky B. Mitotic catastrophe and cancer drug resistance: a link that must to be broken. Drug Resist Updates Rev Comment Antimicrob Anticancer Chemother. 2016;24:1-12

22. Wang Q, Fan S, Eastman A, Worland PJ, Sausville EA, O'Connor PM. UCN01: a potent abrogator of $\mathrm{G} 2$ checkpoint function in cancer cells with disrupted p53. J Natl Cancer Inst. 1996:88:956-65.

23. Beermann J, Piccoli M, Viereck J, Thum T. Non-coding RNAs in development and disease: background, mechanisms, and therapeutic approaches. Physiol Rev. 2016;96:1297-325.

24. Joerger AC, Fersht AR. Structural biology of the tumor suppressor p53 and cancer-associated mutants. Adv Cancer Res. 2007;97:1-23.

25. Bromley D, Daggett $V$. Tumorigenic p53 mutants undergo common structural disruptions including conversion to a-sheet structure. Protein Sci Publ Protein Soc. 2020;29:1983-99.

26. Zhu G, Pan C, Bei J-X, Li B, Liang C, Xu Y, Fu X. Mutant p53 in cancer progression and targeted therapies. Front Oncol. 2020;10:595187.
27. Levine AJ. Targeting therapies for the p53 protein in cancer treatments. Annu Rev Cancer Biol. 2019;3:21-34.

28. Duffy MJ, Synnott NC, O'Grady S, Crown J. Targeting p53 for the treatment of cancer. Semin Cancer Biol. 2020.

29. Leng P, Brown DR, Shivakumar CV, Deb S, Deb SP. N-terminal 130 amino acids of MDM2 are sufficient to inhibit p53-mediated transcriptional activation. Oncogene. 1995:10:1275-82.

30. Freedman DA, Wu L, Levine AJ. Functions of the MDM2 oncoprotein. Cell Mol Life Sci. 1999:55:96-107.

31. Oliner JD, Kinzler KW, Meltzer PS, George DL, Vogelstein B. Amplification of a gene encoding a p53-associated protein in human sarcomas. Nature. 1992;358:80-3.

32. Leach FS, Tokino T, Meltzer P, Burrell M, Oliner JD, Smith S, Hill DE, Sidransky D, Kinzler KW, Vogelstein B. p53 mutation and MDM2 amplification in human soft tissue sarcomas. Can Res. 1993;53:2231-4.

33. Oliner JD, Saiki AY, Caenepeel S. The role of MDM2 amplification and overexpression in tumorigenesis. Cold Spring Harb Perspect Med. 2016:6:a026336.

34. Marine JC, Francoz S, Maetens M, Wahl G, Toledo F, Lozano G. Keeping p53 in check: essential and synergistic functions of Mdm2 and Mdm4. Cell Death Differ. 2006;13:927-34.

35. Moran DM, Maki CG. Nutlin-3a induces cytoskeletal rearrangement and inhibits the migration and invasion capacity of p53 wild-type cancer cells. Mol Cancer Ther. 2010;9:895-905.

36. Luo H, Yount C, Lang H, Yang A, Riemer EC, Lyons K, Vanek KN, Silvestri GA, Schulte BA, Wang GY. Activation of p53 with Nutlin-3a radiosensitizes lung cancer cells via enhancing radiation-induced premature senescence. Lung Cancer (Amsterdam, Netherlands). 2013;81:167-73.

37. Chappell WH, Lehmann BD, Terrian DM, Abrams SL, Steelman LS, McCubrey JA. p53 expression controls prostate cancer sensitivity to chemotherapy and the MDM2 inhibitor Nutlin-3. Cell Cycle (Georgetown, Tex). 2012;11:4579-88.

38. Ray-Coquard I, Blay J-Y, Italiano A, Le Cesne A, Penel N, Zhi J, Heil F, Rueger R, Graves B, Ding M, et al. Effect of the MDM2 antagonist RG7112 on the P53 pathway in patients with MDM2-amplified, well-differentiated or dedifferentiated liposarcoma: an exploratory proof-of-mechanism study. Lancet Oncol. 2012;13:1133-40.

39. Graves B, Thompson T, Xia M, Janson C, Lukacs C, Deo D, Di Lello P, Fry D, Garvie C, Huang K-S, et al. Activation of the p53 pathway by smallmolecule-induced MDM2 and MDMX dimerization. Proc Natl Acad Sci USA. 2012;109:11788-93.

40. Carvajal LA, Neriah DB, Senecal A, Benard L, Thiruthuvanathan V, Yatsenko T, Narayanagari S-R, Wheat JC, Todorova TI, Mitchell K, et al. Dual inhibition of MDMX and MDM2 as a therapeutic strategy in leukemia. Sci Transl Med. 2018;10:eaao3003.

41. Pairawan S, Zhao M, Yuca E, Annis A, Evans K, Sutton D, Carvajal L, Ren J-G, Santiago S, Guerlavais $V$, et al. First in class dual MDM2/MDMX inhibitor ALRN-6924 enhances antitumor efficacy of chemotherapy in TP53 wild-type hormone receptor-positive breast cancer models. Breast Cancer Res. 2021;23:29.

42. Khurana A, Shafer DA. MDM2 antagonists as a novel treatment option for acute myeloid leukemia: perspectives on the therapeutic potential of idasanutlin (RG7388). Onco Targets Ther. 2019:12:2903-10.

43. Konopleva M, Martinelli G, Daver N, Papayannidis C, Wei A, Higgins B, Ott M, Mascarenhas J, Andreeff M. MDM2 inhibition: an important step forward in cancer therapy. Leukemia. 2020;34:2858-74.

44. Yee K, Papayannidis C, vey N, Dickinson MJ, Kelly KR, Assouline S, Kasner M, Seiter K, Drummond MW, Yoon S-S, et al. Murine double minute 2 inhibition alone or with cytarabine in acute myeloid leukemia: results from an idasanutlin phase 1/1b study $\star$. Leuk Res. 2021:100:106489.

45. Zhang W, Guo XY, Hu GY, Liu WB, Shay JW, Deisseroth AB. A temperature-sensitive mutant of human p53. EMBO J. 1994:13:2535-44.

46. Nikolova PV, Wong KB, DeDecker B, Henckel J, Fersht AR. Mechanism of rescue of common p53 cancer mutations by second-site suppressor mutations. EMBO J. 2000;19:370-8.

47. Friedler A, Hansson LO, Veprintsev DB, Freund SMV, Rippin TM, Nikolova PV, Proctor MR, Rüdiger S, Fersht AR. A peptide that binds and stabilizes p53 core domain: chaperone strategy for rescue of oncogenic mutants. Proc Natl Acad Sci USA. 2002;99:937-42.

48. Sallman DA, DeZern AE, Garcia-Manero G, Steensma DP, Roboz GJ, Sekeres MA, Cluzeau T, Sweet KL, McLemore A, McGraw KL, et al. 
Eprenetapopt (APR-246) and azacitidine in -mutant myelodysplastic syndromes. J Clin Oncol Off J Am Soc Clin Oncol. 2021;39:1584-94.

49. Joerger AC, Fersht AR. The p53 pathway: origins, inactivation in cancer, and emerging therapeutic approaches. Annu Rev Biochem. 2016:85:375-404

50. Peng X, Zhang MQZ, Conserva F, Hosny G, Selivanova G, Bykov VJN, Arnér ESJ, Wiman KG. APR-246/PRIMA-1MET inhibits thioredoxin reductase 1 and converts the enzyme to a dedicated NADPH oxidase. Cell Death Dis. 2013:4:e881.

51. Guo Z, Tsai M-H, Shiao Y-H, Chen L-H, Wei M-L, Lv X, Gius D, Little JB, Mitchell JB, Chuang EY. DNA (cytosine-5)-methyltransferase 1 as a mediator of mutant p53-determined p16(ink4A) down-regulation. J Biomed Sci. 2008;15:163-8.

52. Subramanian M, Francis P, Bilke S, Li XL, Hara T, Lu X, Jones MF, Walker RL, Zhu Y, Pineda M, et al. A mutant p53/let-7i-axis-regulated gene network drives cell migration, invasion and metastasis. Oncogene. 2015;34:1094-104.

53. Terzian T, Suh Y-A, Iwakuma T, Post SM, Neumann M, Lang GA, Van Pelt CS, Lozano $\mathrm{G}$. The inherent instability of mutant p53 is alleviated by Mdm2 or p16INK4a loss. Genes Dev. 2008:22:1337-44.

54. West AC, Johnstone RW. New and emerging HDAC inhibitors for cancer treatment. J Clin Investig. 2014;124:30-9.

55. Yan W, Liu S, Xu E, Zhang J, Zhang Y, Chen X, Chen X. Histone deacetylase inhibitors suppress mutant p53 transcription via histone deacetylase 8. Oncogene. 2013;32:599-609.

56. Li D, Marchenko ND, Moll UM. SAHA shows preferential cytotoxicity in mutant p53 cancer cells by destabilizing mutant p53 through inhibition of the HDAC6-Hsp90 chaperone axis. Cell Death Differ. 2011;18:1904-13.

57. Lin K, Rockliffe N, Johnson GG, Sherrington PD, Pettitt AR. Hsp90 inhibition has opposing effects on wild-type and mutant p53 and induces p21 expression and cytotoxicity irrespective of p53/ATM status in chronic lymphocytic leukaemia cells. Oncogene. 2008;27:2445-55.

58. Wang J, Zhao Q, Qi Q, Gu H, Rong J, Mu R, Zou M, Tao L, You Q, Guo Q. Gambogic acid-induced degradation of mutant p53 is mediated by proteasome and related to CHIP. J Cell Biochem. 2011;112:509-19.

59. Ho TCS, Chan AHY, Ganesan A. Thirty years of HDAC inhibitors: 2020 insight and hindsight. J Med Chem. 2020;63:12460-84.

60. Trepel J, Mollapour M, Giaccone G, Neckers L. Targeting the dynamic HSP90 complex in cancer. Nat Rev Cancer. 2010;10:537-49.

61. Andreeff M, Kelly KR, Yee K, Assouline S, Strair R, Popplewell L, Bowen D, Martinelli G, Drummond MW, Vyas P, et al. Results of the phase I trial of RG7112, a small-molecule MDM2 antagonist in leukemia. Clin Cancer Res Off J Am Assoc Cancer Res. 2016;22:868-76.

62. Kabeche L, Nguyen HD, Buisson R, Zou L. A mitosis-specific and R loop-driven ATR pathway promotes faithful chromosome segregation. Science (New York, NY). 2018:359:108-14.

63. Qiu Z, Oleinick NL, Zhang J. ATR/CHK1 inhibitors and cancer therapy. Radiother Oncol J Eur Soc Ther Radiol Oncol. 2018;126:450-64.

64. Song J, Yu J, Jeong LS, Lee SK. A novel cytarabine analog evokes synthetic lethality by targeting MK2 in p53-deficient cancer cells. Cancer Lett. 2021;497:54-65.

65. Krajewska M, Heijink AM, Bisselink YJWM, Seinstra RI, Silljé HHW, de Vries EGE, van Vugt MATM. Forced activation of Cdk1 via wee1 inhibition impairs homologous recombination. Oncogene. 2013;32:3001-8.

66. Cimprich KA, Cortez D. ATR: an essential regulator of genome integrity. Nat Rev Mol Cell Biol. 2008:9:616-27.

67. Reaper PM, Griffiths MR, Long JM, Charrier J-D, Maccormick S, Charlton PA, Golec JMC, Pollard JR. Selective killing of ATM- or p53-deficient cancer cells through inhibition of ATR. Nat Chem Biol. 2011;7:428-30.

68. Konstantinopoulos PA, Cheng S-C, Wahner Hendrickson AE, Penson RT, Schumer ST, Doyle LA, Lee EK, Kohn EC, Duska LR, Crispens MA, et al. Berzosertib plus gemcitabine versus gemcitabine alone in platinumresistant high-grade serous ovarian cancer: a multicentre, open-label, randomised, phase 2 trial. Lancet Oncol. 2020;21:957-68.

69. Tuna M, Ju Z, Yoshihara K, Amos Cl, Tanyi JL, Mills GB. Clinical relevance of TP53 hotspot mutations in high-grade serous ovarian cancers. Br J Cancer. 2020;122:405-12.

70. Parmar K, Kochupurakkal BS, Lazaro J-B, Wang ZC, Palakurthi S, Kirschmeier PT, Yang C, Sambel LA, Färkkilä A, Reznichenko E, et al. The CHK1 inhibitor prexasertib exhibits monotherapy activity in high-grade serous ovarian cancer models and sensitizes to PARP inhibition. Clin Cancer Res Off J Am Assoc Cancer Res. 2019;25:6127-40.

71. Fang B. Development of synthetic lethality anticancer therapeutics. J Med Chem. 2014;57:7859-73.

72. Reinhardt HC, Aslanian AS, Lees JA, Yaffe MB. p53-deficient cells rely on ATM- and ATR-mediated checkpoint signaling through the p38MAPK/MK2 pathway for survival after DNA damage. Cancer Cell. 2007;11:175-89.

73. Meng X, Laidler LL, Kosmacek EA, Yang S, Xiong Z, Zhu D, Wang X, Dai $D$, Zhang $Y$, Wang $X$, et al. Induction of mitotic cell death by overriding G2/M checkpoint in endometrial cancer cells with non-functional p53. Gynecol Oncol. 2013;128:461-9.

74. Schmidt M, Rohe A, Platzer C, Najjar A, Erdmann F, Sippl W. Regulation of G2/M transition by inhibition of WEE1 and PKMYT1 kinases. Molecules (Basel, Switzerland). 2017;22:2045.

75. Mueller PR, Coleman TR, Kumagai A, Dunphy WG. Myt1: a membraneassociated inhibitory kinase that phosphorylates $\mathrm{Cdc}$ on both threonine-14 and tyrosine-15. Science (New York, NY). 1995;270:86-90.

76. Bridges KA, Hirai H, Buser CA, Brooks C, Liu H, BuchholzTA, Molkentine JM, Mason KA, Meyn RE. MK-1775, a novel Wee1 kinase inhibitor, radiosensitizes p53-defective human tumor cells. Clin Cancer Res Off J Am Assoc Cancer Res. 2011;17:5638-48.

77. Méndez E, Rodriguez CP, Kao MC, Raju S, Diab A, Harbison RA, Konnick EQ, Mugundu GM, Santana-Davila R, Martins R, et al. A phase I clinical trial of AZD1775 in combination with neoadjuvant weekly docetaxel and cisplatin before definitive therapy in head and neck squamous cell carcinoma. Clin Cancer Res Off J Am Assoc Cancer Res. 2018:24:2740-8.

78. Zitouni S, Nabais C, Jana SC, Guerrero A, Bettencourt-Dias M. Polo-like kinases: structural variations lead to multiple functions. Nat Rev Mol Cell Biol. 2014;15:433-52.

79. Vose JM, Friedberg JW, Waller EK, Cheson BD, Juvvigunta V, Fritsch $\mathrm{H}$, Petit C, Munzert G, Younes A. The PIk1 inhibitor BI 2536 in patients with refractory or relapsed non-Hodgkin lymphoma: a phase I, open-label, single dose-escalation study. Leuk Lymphoma. 2013;54:708-13.

80. Vousden KH, Ryan KM. p53 and metabolism. Nat Rev Cancer. 2009:9:691-700.

81. Schwartzenberg-Bar-Yoseph F, Armoni M, Karnieli E. The tumor suppressor p53 down-regulates glucose transporters GLUT1 and GLUT4 gene expression. Can Res. 2004;64:2627-33.

82. Kawauchi K, Araki K, Tobiume K, Tanaka N. p53 regulates glucose metabolism through an IKK-NF-kappaB pathway and inhibits cell transformation. Nat Cell Biol. 2008;10:611-8.

83. Wanka C, Brucker DP, Bähr O, Ronellenfitsch M, Weller M, Steinbach JP, Rieger J. Synthesis of cytochrome C oxidase 2: a p53-dependent metabolic regulator that promotes respiratory function and protects glioma and colon cancer cells from hypoxia-induced cell death. Oncogene. 2012:31:3764-76

84. Vahsen N, Candé C, Brière J-J, Bénit P, Joza N, Larochette N, Mastroberardino PG, Pequignot MO, Casares N, Lazar V, et al. AlF deficiency compromises oxidative phosphorylation. EMBO J. 2004;23:4679-89.

85. Hanahan D, Weinberg RA. Hallmarks of cancer: the next generation. Cell. 2011;144:646-74.

86. Zhang C, Liu J, Liang Y, Wu R, Zhao Y, Hong X, Lin M, Yu H, Liu L, Levine AJ, et al. Tumour-associated mutant p53 drives the Warburg effect. Nat Commun. 2013:4:2935.

87. Mathupala SP, Heese C, Pedersen PL. Glucose catabolism in cancer cells. The type II hexokinase promoter contains functionally active response elements for the tumor suppressor p53. J Biol Chem. 1997:272:22776-80.

88. Wang L, Xiong H, Wu F, Zhang Y, Wang J, Zhao L, Guo X, Chang L-J, Zhang Y, You MJ, et al. Hexokinase 2-mediated Warburg effect is required for PTEN- and p53-deficiency-driven prostate cancer growth. Cell Rep. 2014;8:1461-74.

89. Emerling BM, Hurov JB, Poulogiannis G, Tsukazawa KS, Choo-Wing R, Wulf GM, Bell EL, Shim H-S, Lamia KA, Rameh LE, et al. Depletion of a putatively druggable class of phosphatidylinositol kinases inhibits growth of p53-null tumors. Cell. 2013;155:844-57.

90. Liu J, Liu Z-X, Wu Q-N, Lu Y-X, Wong C-W, Miao L, Wang Y, Wang Z, Jin Y, He M-M, et al. Long noncoding RNA AGPG regulates PFKFB3-mediated tumor glycolytic reprogramming. Nat Commun. 2020;11:1507. 
91. Eriksson M, Ambroise G, Ouchida AT, Lima Queiroz A, Smith D, Gimenez-Cassina A, Iwanicki MP, Muller PA, Norberg E, VakifahmetogluNorberg $\mathrm{H}$. Effect of mutant p53 proteins on glycolysis and mitochondrial metabolism. Mol Cell Biol. 2017;37:e00328-17.

92. Ben Sahra I, Laurent K, Giuliano S, Larbret F, Ponzio G, Gounon P, Le Marchand-Brustel Y, Giorgetti-Peraldi S, Cormont M, Bertolotto C, et al. Targeting cancer cell metabolism: the combination of metformin and 2-deoxyglucose induces p53-dependent apoptosis in prostate cancer cells. Can Res. 2010;70:2465-75.

93. Yu L, Chen Y, Tooze SA. Autophagy pathway: cellular and molecular mechanisms. Autophagy. 2018;14:207-15.

94. Onorati AV, Dyczynski M, Ojha R, Amaravadi RK. Targeting autophagy in cancer. Cancer. 2018;124:3307-18.

95. Cordani M, Butera G, Pacchiana R, Donadelli M. Molecular interplay between mutant p53 proteins and autophagy in cancer cells. Biochim Biophys Acta. 2017;1867:19-28.

96. Cordani M, Oppici E, Dando I, Butturini E, Dalla Pozza E, Nadal-Serrano M, Oliver J, Roca P, Mariotto S, Cellini B, et al. Mutant p53 proteins counteract autophagic mechanism sensitizing cancer cells to mTOR inhibition. Mol Oncol. 2016:10:1008-29.

97. D'Orazi G, Cirone M. Mutant p53 and cellular stress pathways: a criminal alliance that promotes cancer progression. Cancers. 2019;11:614.

98. Shi Y, Norberg E, Vakifahmetoglu-Norberg H. Mutant p53 as a regulator and target of autophagy. Front Oncol. 2020;10:607149.

99. Vakifahmetoglu-Norberg H, Kim M, Xia H, Iwanicki MP, Ofengeim D, Coloff JL, Pan L, Ince TA, Kroemer G, Brugge JS, Yuan J. Chaperone-mediated autophagy degrades mutant p53. Genes Dev. 2013;27:1718-30.

100. Roger L, Jullien L, Gire V, Roux P. Gain of oncogenic function of p53 mutants regulates $\mathrm{E}$-cadherin expression uncoupled from cell invasion in colon cancer cells. J Cell Sci. 2010:123:1295-305.

101. Jacquemet G, Green DM, Bridgewater RE, von Kriegsheim A, Humphries MJ, Norman JC, Caswell PT. RCP-driven a5 $\beta 1$ recycling suppresses Rac and promotes RhoA activity via the RacGAP1-IQGAP1 complex. J Cell Biol. 2013;202:917-35.

102. Tang Q, Su Z, Gu W, Rustgi AK. Mutant p53 on the path to metastasis. Trends Cancer. 2020;6:62-73.

103. Weissmueller S, Manchado E, Saborowski M, Morris JP, Wagenblast E, Davis CA, Moon S-H, Pfister NT, Tschaharganeh DF, Kitzing T, et al. Mutant p53 drives pancreatic cancer metastasis through cell-autonomous PDGF receptor $\beta$ signaling. Cell. 2014;157:382-94.

104. Xiong S, Tu H, Kollareddy M, Pant V, Li Q, Zhang Y, Jackson JG, Suh Y-A, Elizondo-Fraire AC, Yang P, et al. Pla2g16 phospholipase mediates gain-of-function activities of mutant p53. Proc Natl Acad Sci USA. 2014;111:11145-50

105. Slack F, Chinnaiyan A. The role of non-coding RNAs in oncology. Cell. 2019;179:1033-55.

106. Bushati N, Cohen S. microRNA functions. Annu Rev Cell Dev Biol. 2007:23:175-205.

107. Quinn J, Chang H. Unique features of long non-coding RNA biogenesis and function. Nat Rev Genet. 2016;17:47-62.

108. Sargolzaei J, Etemadi T, Alyasin A. The P53/microRNA network: a potential tumor suppressor with a role in anticancer therapy. Pharmacol Res. 2020;160:105179.

109. Chaudhary R, Lal A. Long noncoding RNAs in the p53 network. Wiley Interdiscip Rev RNA. 2017;8:e1410.

110. Di Agostino S. The impact of mutant p53 in the non-coding RNA world. Biomolecules. 2020;10(3):472.

111. Fabian M, Sonenberg N, Filipowicz W. Regulation of mRNA translation and stability by microRNAs. Annu Rev Biochem. 2010;79:351-79.

112. Krell J, Frampton AE, Colombo T, Gall TMH, De Giorgio A, Harding V, Stebbing J, Castellano L. The p53 miRNA interactome and its potential role in the cancer clinic. Epigenomics. 2013;5:417-28.

113. Ju Q, Zhao L, Gao J, Zhou L, Xu Y, Sun Y, Zhao X. Mutant $p 53$ increases exosome-mediated transfer of miR-21-3p and miR-769-3p to promote pulmonary metastasis. Chin J Cancer Res. 2019:31:533-46.

114. Grespi F, Landre V, Molchadsky A, Di Daniele N, Marsella LT, Melino G, Rotter V. Differential regulated microRNA by wild type and mutant p53 in induced pluripotent stem cells. Cell Death Dis. 2016;7:e2567.

115. Chen $X$, Liang H, Zhang J, Zen K, Zhang C-Y. Secreted microRNAs: a new form of intercellular communication. Trends Cell Biol. 2012;22:125-32.
116. Tarasov V, Jung P, Verdoodt B, Lodygin D, Epanchintsev A, Menssen A, Meister $\mathrm{G}$, Hermeking $\mathrm{H}$. Differential regulation of microRNAs by p53 revealed by massively parallel sequencing: $\mathrm{miR}-34 \mathrm{a}$ is a p53 target that induces apoptosis and G1-arrest. Cell Cycle (Georgetown, Tex). 2007:6:1586-93.

117. Jiang L, Hermeking H. miR-34a and miR-34b/c suppress intestinal tumorigenesis. Can Res. 2017;77:2746-58.

118. Park EY, Chang E, Lee EJ, Lee H-W, Kang H-G, Chun K-H, Woo YM, Kong HK, Ko JY, Suzuki H, et al. Targeting of miR34a-NOTCH1 axis reduced breast cancer stemness and chemoresistance. Can Res. 2014;74:7573-82.

119. Kasinski AL, Slack FJ. miRNA-34 prevents cancer initiation and progression in a therapeutically resistant K-ras and p53-induced mouse model of lung adenocarcinoma. Can Res. 2012;72:5576-87.

120. Zhang Y, Wang Z, Gemeinhart RA. Progress in microRNA delivery. J Control Release Off J Control Release Soc. 2013;172:962-74.

121. Hong DS, Kang Y-K, Borad M, Sachdev J, Ejadi S, Lim HY, Brenner AJ, Park K, Lee J-L, Kim T-Y, et al. Phase 1 study of MRX34, a liposomal miR-34a mimic, in patients with advanced solid tumours. Br J Cancer. 2020;122:1630-7.

122. Masciarelli S, Fontemaggi G, Di Agostino S, Donzelli S, Carcarino E, Strano S, Blandino G. Gain-of-function mutant p53 downregulates miR-223 contributing to chemoresistance of cultured tumor cells. Oncogene. 2014;33:1601-8.

123. Luo P, Wang Q, Ye Y, Zhang J, Lu D, Cheng L, Zhou H, Xie M, Wang B. MiR-223-3p functions as a tumor suppressor in lung squamous cell carcinoma by miR-223-3p-mutant p53 regulatory feedback loop. J Exp Clin Cancer Res. 2019;38:74

124. Capaci V, Bascetta L, Fantuz M, Beznoussenko GV, Sommaggio R, Cancila V, Bisso A, Campaner E, Mironov AA, Wisniewski JR, et al. Mutant p53 induces Golgi tubulo-vesiculation driving a prometastatic secretome. Nat Commun. 2020;11:445-54.

125. Waniczek D, Lorenc Z, Snietura M, Wesecki M, Kopec A, Muc-Wierzgon $M$. Tumor-associated macrophages and regulatory $T$ cells infiltration and the clinical outcome in colorectal cancer. Arch Immunol Ther Exp. 2017:65:445-54.

126. Tragante V, Moore JH, Asselbergs FW. The ENCODE project and perspectives on pathways. Genet Epidemiol. 2014:38:275-80.

127. Harrow J, Frankish A, Gonzalez JM, Tapanari E, Diekhans M, Kokocinski F, Aken BL, Barrell D, Zadissa A, Searle S, et al. GENCODE: the reference human genome annotation for the ENCODE project. Genome Res. 2012:22:1760-74.

128. Bhartiya D, Pal K, Ghosh S, Kapoor S, Jalali S, Panwar B, Jain S, Sati S, Sengupta S, Sachidanandan C, et al. IncRNome: a comprehensive knowledgebase of human long noncoding RNAs. Database J Biol Databases Curation. 2013:2013:bat034.

129. Volders P-J, Verheggen K, Menschaert G, Vandepoele K, Martens L, Vandesompele J, Mestdagh P. An update on LNCipedia: a database for annotated human IncRNA sequences. Nucleic Acids Res. 2015;43:D174-80.

130. Dhanoa JK, Sethi RS, Verma R, Arora JS, Mukhopadhyay CS. Long non-coding RNA: its evolutionary relics and biological implications in mammals: a review. J Anim Sci Technol. 2018:60:25.

131. Kopp F, Mendell JT. Functional classification and experimental dissection of long noncoding RNAs. Cell. 2018;172:393-407.

132. Loos F, Maduro C, Loda A, Lehmann J, Kremers G-J, Ten Berge D, Grootegoed JA, Gribnau J. Xist and Tsix transcription dynamics is regulated by the $\mathrm{X}$-to-autosome ratio and semistable transcriptional states. Mol Cell Biol. 2016;36:2656-67.

133. Esquerra JLS, Ofori JK, Nagao M, Shuto Y, Karagiannopoulos A, Fadista J, Sugihara H, Groop L, Eliasson L. Glucocorticoid induces human beta cell dysfunction by involving riborepressor GAS5 LincRNA. Mol Metab. 2020;32:160-7.

134. Meseure D, Vacher S, Alsibai KD, Nicolas A, Chemlali W, Caly M, Lidereau R, Pasmant E, Callens C, Bieche I. Expression of ANRIL-polycomb complexes-CDKN2A/B/ARF genes in breast tumors: identification of a two-gene (EZH2/CBX7) signature with independent prognostic value. Mol Cancer Res. 2016;14:623-33.

135. Sun T-T, He J, Liang Q, Ren L-L, Yan T-T, Yu T-C, Tang J-Y, Bao Y-J, Hu Y, Lin $Y$, et al. LncRNA GClnc1 promotes gastric carcinogenesis and may act 
as a modular scaffold of WDR5 and KAT2A complexes to specify the histone modification pattern. Cancer Discov. 2016;6:784-801.

136. Blume CJ, Hotz-Wagenblatt A, Hüllein J, Sellner L, Jethwa A, Stolz T, Slabicki M, Lee K, Sharathchandra A, Benner A, et al. p53-dependent non-coding RNA networks in chronic lymphocytic leukemia. Leukemia. 2015;29:2015-23.

137. Jin S, Yang X, Li J, Yang W, Ma H, Zhang Z. p53-targeted lincRNAp21 acts as a tumor suppressor by inhibiting JAK2/STAT3 signaling pathways in head and neck squamous cell carcinoma. Mol Cancer. 2019;18:38.

138. Pruszko M, Milano E, Forcato M, Donzelli S, Ganci F, Di Agostino S, De Panfilis S, Fazi F, Bates DO, Bicciato S, et al. The mutant p53-ID4 complex controls VEGFA isoforms by recruiting InCRNA MALAT1. EMBO Rep. 2017:18:1331-51.

139. Kristensen LS, Andersen MS, Stagsted LVW, Ebbesen KK, Hansen TB, Kjems J. The biogenesis, biology and characterization of circular RNAs. Nat Rev Genet. 2019;20:675-91.

140. Fang L, Du WW, Lyu J, Dong J, Zhang C, Yang W, He A, Kwok YSS, Ma J, Wu N, et al. Enhanced breast cancer progression by mutant p53 is inhibited by the circular RNA circ-Ccnb1. Cell Death Differ. 2018;25:2195-208

141. Matsui M, Corey DR. Non-coding RNAs as drug targets. Nat Rev Drug Discov. 2017;16:167-79.

142. Martin JD, Cabral H, Stylianopoulos T, Jain RK. Improving cancer immunotherapy using nanomedicines: progress, opportunities and challenges. Nat Rev Clin Oncol. 2020;17:251-66.

143. Fang DD, Tang Q, Kong Y, Wang Q, Gu J, Fang X, Zou P, Rong T, Wang J, Yang D, Zhai Y. MDM2 inhibitor APG-115 synergizes with PD-1 blockade through enhancing antitumor immunity in the tumor microenvironment. J Immunother Cancer. 2019;7:327.

144. Solares MJ, Jonaid GM, Luqiu WY, Liang Y, Evans MC, Dearnaley WJ, Sheng Z, Kelly DF. Microchip-based structure determination of diseaserelevant p53. Anal Chem. 2020;92:15558-64.

145. Sun C, Cao W, Qiu C, Li C, Dongol S, Zhang Z, Dong R, Song K, Yang X, Zhang Q, Kong B. MiR-509-3 augments the synthetic lethality of PARPi by regulating HR repair in PDX model of HGSOC. J Hematol Oncol. 2020;13:9.

146. Erba HP, Becker PS, Shami PJ, Grunwald MR, Flesher DL, Zhu M, Rasmussen E, Henary HA, Anderson AA, Wang ES. Phase 1b study of the MDM2 inhibitor AMG 232 with or without trametinib in relapsed/refractory acute myeloid leukemia. Blood Adv. 2019;3:1939-49.

147. Patnaik A, Tolcher A, Beeram M, Nemunaitis J, Weiss GJ, Bhalla K Agrawal M, Nichols G, Middleton S, Beryozkina A, et al. Clinical pharmacology characterization of RG7112, an MDM2 antagonist, in patients with advanced solid tumors. Cancer Chemother Pharmacol. 2015;76:587-95.

148. Uy GL, Assouline S, Young A-M, Blotner S, Higgins B, Chen L-C, Yee K Phase 1 study of the MDM2 antagonist RO6839921 in patients with acute myeloid leukemia. Invest New Drugs. 2020;38:1430-41.

149. Abdul Razak AR, Miller WH, Uy GL, Blotner S, Young A-M, Higgins B, Chen L-C, Gore L. A phase 1 study of the MDM2 antagonist RO6839921, a pegylated prodrug of idasanutlin, in patients with advanced solid tumors. Invest New Drugs. 2020;38:1156-65.

150. Saleh MN, Patel MR, Bauer TM, Goel S, Falchook GS, Shapiro Gl, Chung KY, Infante JR, Conry RM, Rabinowits G, et al. Phase 1 trial of ALRN-6924, a dual inhibitor of MDMX and MDM2, in patients with solid tumors and lymphomas bearing wild-type. Clin Cancer Res Off J Am Assoc Cancer Res. 2021.

151. Italiano A, Miller WH, Blay J-Y, Gietema JA, Bang Y-J, Mileshkin LR, Hirte HW, Higgins B, Blotner S, Nichols GL, et al. Phase I study of daily and weekly regimens of the orally administered MDM2 antagonist idasanutlin in patients with advanced tumors. Investig New Drugs. 2021.

152. Pápai Z, Chen L-C, Da Costa D, Blotner S, Vazvaei F, Gleave M, Jones $\mathrm{R}$, Zhi J. A single-center, open-label study investigating the excretion balance, pharmacokinetics, metabolism, and absolute bioavailability of a single oral dose of [C]-labeled idasanutlin and an intravenous tracer dose of [C]-labeled idasanutlin in a single cohort of patients with solid tumors. Cancer Chemother Pharmacol. 2019;84:93-103.

153. Bauer S, Demetri GD, Halilovic E, Dummer R, Meille C, Tan DSW, Guerreiro N, Jullion A, Ferretti S, Jeay S, et al.
Pharmacokinetic-pharmacodynamic guided optimisation of dose and schedule of CGM097, an HDM2 inhibitor, in preclinical and clinical studies. Br J Cancer. 2021:125:687-98.

154. Jeay S, Ferretti S, Holzer P, Fuchs J, Chapeau EA, Wartmann M, Sterker D, Romanet V, Murakami M, Kerr G, et al. Dose and schedule determine distinct molecular mechanisms underlying the efficacy of the p53MDM2 inhibitor HDM201. Can Res. 2018;78:6257-67.

155. Joerger AC, Fersht AR. Structure-function-rescue: the diverse nature of common p53 cancer mutants. Oncogene. 2007:26:2226-42.

156. Bykov VJN, Issaeva N, Shilov A, Hultcrantz M, Pugacheva E, Chumakov P, Bergman J, Wiman KG, Selivanova G. Restoration of the tumor suppressor function to mutant p53 by a low-molecular-weight compound. Nat Med. 2002;8:282-8.

157. Bykov VJN, Issaeva N, Zache N, Shilov A, Hultcrantz M, Bergman J, Selivanova G, Wiman KG. Reactivation of mutant p53 and induction of apoptosis in human tumor cells by maleimide analogs. J Biol Chem. 2005;280:30384-91

158. Zache N, Lambert JMR, Rokaeus N, Shen J, Hainaut P, Bergman J, Wiman KG, Bykou VN. Mutant p53 targeting by the low molecular weight compound STIMA-1. Mol Oncol. 2008:2:70-80.

159. Bauer MR, Joerger AC, Fersht AR. 2-Sulfonylpyrimidines: mild alkylating agents with anticancer activity toward p53-compromised cells. Proc Natl Acad Sci USA. 2016;113:E5271-80.

160. Blanden AR, Yu X, Wolfe AJ, Gilleran JA, Augeri DJ, O'Dell RS, Olson EC, Kimball SD, Emge TJ, Movileanu L, et al. Synthetic metallochaperone ZMC1 rescues mutant 153 conformation by transporting zinc into cells as an ionophore. Mol Pharmacol. 2015;87:825-31.

161. Synnott NC, O'Connell D, Crown J, Duffy MJ. COTI-2 reactivates mutant p53 and inhibits growth of triple-negative breast cancer cells. Breast Cancer Res Treat. 2020;179:47-56.

162. Soragni A, Janzen DM, Johnson LM, Lindgren AG, Anh Thai-Quynh $N$, Tiourin E, Soriaga AB, Lu J, Jiang L, Faull KF, et al. A designed inhibitor of p53 aggregation rescues p53 tumor suppression in ovarian carcinomas. Cancer Cell. 2016;29:90-103.

163. Kravchenko JE, llyinskaya GV, Komarov PG, Agapova LS, Kochetkov DV, Strom E, Frolova El, Kovriga I, Gudkov AV, Feinstein E, Chumakov PM. Small-molecule RETRA suppresses mutant p53-bearing cancer cells through a p73-dependent salvage pathway. Proc Natl Acad Sci USA. 2008;105:6302-7.

164. Bauer MR, Jones RN, Tareque RK, Springett B, Dingler FA, Verduci L, Patel $\mathrm{KJ}$, Fersht AR, Joerger AC, Spencer J. A structure-guided molecular chaperone approach for restoring the transcriptional activity of the p53 cancer mutant Y220C. Future Med Chem. 2019;11:2491-504.

165. Weinmann L, Wischhusen J, Demma MJ, Naumann U, Roth P, DasMahapatra B, Weller M. A novel p53 rescue compound induces p53-dependent growth arrest and sensitises glioma cells to Apo2L/ TRAlL-induced apoptosis. Cell Death Differ. 2008;15:718-29.

166. Demma M, Maxwell E, Ramos R, Liang L, Li C, Hesk D, Rossman R, Mallams A, Doll R, Liu M, et al. SCH529074, a small molecule activator of mutant p53, which binds p53 DNA binding domain (DBD), restores growth-suppressive function to mutant p53 and Interrupts HDM2-mediated ubiquitination of wild type p53. J Biol Chem. 2010:285:10198-212

167. Boeckler FM, Joerger AC, Jaggi G, Rutherford TJ, Veprintsev DB, Fersht AR. Targeted rescue of a destabilized mutant of p53 by an in silico screened drug. Proc Natl Acad Sci USA. 2008;105:10360-5.

168. Wassman CD, Baronio R, Demir O, Wallentine BD, Chen C-K, Hall LV, Salehi F, Lin D-W, Chung BP, Hatfield GW, et al. Computational identification of a transiently open L1/S3 pocket for reactivation of mutant $\mathrm{p} 53$. Nat Commun. 2013:4:1-9.

169. Hiraki M, Hwang S-Y, Cao S, Ramadhar TR, Byun S, Yoon KW, Lee JH, Chu K, Gurkar AU, Kolev V, et al. Small-molecule reactivation of mutant p53 to wild-type-like p53 through the p53-Hsp40 regulatory axis. Chem Biol. 2015:22:1206-16.

170. Issaeva N, Bozko P, Enge M, Protopopova M, Verhoef L, Masucci M, Pramanik A, Selivanova G. Small molecule RITA binds to p53, blocks p53-HDM-2 interaction and activates p53 function in tumors. Nat Med. 2004:10:1321-8.

171. North S, Pluquet O, Maurici D, El Ghissassi F, Hainaut P. Restoration of wild-type conformation and activity of a temperature-sensitive mutant 
of p53 (p53(V272M)) by the cytoprotective aminothiol WR1065 in the esophageal cancer cell line TE-1. Mol Carcinog. 2002;33:181-8.

172. Burmistrov V, Saxena R, Pitushkin D, Butov GM, Chung F-L, Aggarwal M. Adamantyl isothiocyanates as mutant p53 rescuing agents and their structure-activity relationships. J Med Chem. 2021;64:6621-33.

173. Vaseva AV, Yallowitz AR, Marchenko ND, Xu S, Moll UM. Blockade of Hsp90 by 17AAG antagonizes MDMX and synergizes with Nutlin to induce p53-mediated apoptosis in solid tumors. Cell Death Dis. 2011;2:e156.

174. Parrales A, Thoenen E, Iwakuma T. The interplay between mutant p53 and the mevalonate pathway. Cell Death Differ. 2018;25:460-70

175. Zhang S, Zhou L, Hong B, van den Heuvel APJ, Prabhu W, Warfel NA, Kline CLB, Dicker DT, Kopelovich L, El-Deiry WS. Small-molecule NSC59984 restores p53 pathway signaling and antitumor effects against colorectal cancer via p73 activation and degradation of mutant p53. Can Res. 2015;75:3842-52.

176. Paranjpe A, Srivenugopal K. Degradation of NF-KB, p53 and other regulatory redox-sensitive proteins by thiol-conjugating and -nitrosylating drugs in human tumor cells. Carcinogenesis. 2013;34:990-1000.

177. Thomas A, Redon CE, Sciuto L, Padiernos E, Ji J, Lee M-J, Yuno A, Lee S, Zhang Y, Tran L, et al. Phase I study of ATR inhibitor M6620 in combination with topotecan in patients with advanced solid tumors. J Clin Oncol Off J Am Soc Clin Oncol. 2018;36:1594-602.

178. Wang H, Wang L, Zhang Y, Wang J, Deng Y, Lin D. Inhibition of glycolytic enzyme hexokinase II (HK2) suppresses lung tumor growth. Cancer Cell Int. 2016;16:9.

179. Dong P, Karaayvaz M, Jia N, Kaneuchi M, Hamada J, Watari H, Sudo S, Ju J, Sakuragi N. Mutant p53 gain-of-function induces epithelial-mesenchymal transition through modulation of the miR-130b-ZEB1 axis. Oncogene. 2013;32:3286-95.

180. Cooks T, Pateras IS, Jenkins LM, Patel KM, Robles Al, Morris J, Forshew T, Appella E, Gorgoulis VG, Harris CC. Mutant p53 cancers reprogram macrophages to tumor supporting macrophages via exosomal miR-1246. Nat Commun. 2018;9:1-15.
181. Welponer H, Tsibulak I, Wieser V, Degasper C, Shivalingaiah G, Wenzel S, Sprung S, Marth C, Hackl H, Fiegl H, Zeimet AG. The miR-34 family and its clinical significance in ovarian cancer. J Cancer. 2020;11:1446-56.

182. Roybal JD, Zang Y, Ahn Y-H, Yang Y, Gibbons DL, Baird BN, Alvarez C, Thilaganathan N, Liu DD, Saintigny P, et al. miR-200 inhibits lung adenocarcinoma cell invasion and metastasis by targeting Flt1/NEGFR1. Mol Cancer Res. 2011:9:25-35.

183. Godfrey JD, Morton JP, Wilczynska A, Sansom OJ, Bushell MD. MiR$142-3 p$ is downregulated in aggressive p53 mutant mouse models of pancreatic ductal adenocarcinoma by hypermethylation of its locus. Cell Death Dis. 2018;9:1-14

184. Zhao Y, Li Y, Sheng J, Wu F, Li K, Huang R, Wang X, Jiao T, Guan X, Lu $Y$, et al. P53-R273H mutation enhances colorectal cancer stemness through regulating specific IncRNAs. J Exp Clin Cancer Res. 2019;38:379.

185. Di Agostino S, Valenti F, Sacconi A, Fontemaggi G, Pallocca M, Pulito C, Ganci F, Muti P, Strano S, Blandino G. Long non-coding MIR205HG depletes Hsa-miR-590-3p leading to unrestrained proliferation in head and neck squamous cell carcinoma. Theranostics. 2018;8:1850-68.

186. Meng X, Sun W, Yu J, Zhou Y, Gu Y, Han J, Zhou L, Jiang X, Wang C. LINC00460-miR-149-5p/miR-150-5p-mutant p53 feedback loop promotes oxaliplatin resistance in colorectal cancer. Mol Ther Nucleic Acids. 2020;22:1004-15.

187. Verduci L, Ferraiuolo M, Sacconi A, Ganci F, Vitale J, Colombo T, Paci P, Strano S, Macino G, Rajewsky N, Blandino G. The oncogenic role of circPVT1 in head and neck squamous cell carcinoma is mediated through the mutant P53/YAP/TEAD transcription-competent complex. Genome Biol. 2017;18:237.

\section{Publisher's Note}

Springer Nature remains neutral with regard to jurisdictional claims in published maps and institutional affiliations.
Ready to submit your research? Choose BMC and benefit from:

- fast, convenient online submission

- thorough peer review by experienced researchers in your field

- rapid publication on acceptance

- support for research data, including large and complex data types

- gold Open Access which fosters wider collaboration and increased citations

- maximum visibility for your research: over $100 \mathrm{M}$ website views per year

At BMC, research is always in progress.

Learn more biomedcentral.com/submissions 